UC3M Working papers

Economics

17-07

July, 2017

ISSN 2340-5031
Departamento de Economía Universidad Carlos III de Madrid

Calle Madrid, 126

28903 Getafe (Spain)

Fax (34) 916249875

\title{
Nonlinear and asymmetric pricing behaviour in the Spanish gasoline market
}

\author{
Álvaro Escribano ${ }^{1}$ \\ Department of Economics, Universidad Carlos III de Madrid \\ and \\ María Torrado , Universidad Carlos III de Madrid
}

\begin{abstract}
Over the last decades a transition from a state-own monopoly to a private business took place in the Spanish fuel sector. To figure out whether downstream prices react differently to upstream price increases than to price decreases, alternative dynamic nonlinear and asymmetric error correction models are applied to weekly price data. This paper analyse the existence of price asymmetries in the fuel market in Spain during the 2011-2016 period. In comparison with traditional asymmetric price theory literature, this paper introduces a new double threshold error correction (ECM) model (DT-ECM) and new double logistic ECM models and compares them with more common linear ECM, time varying parameter models (TV-ECM), threshold autoregressive models (T-ECM), smooth transition autoregressive (STAR) models and nonlinear error correction (Logistic-ECM) and double threshold Logistic (DT-Logistic ECM). The nonlinear and asymmetric results found show that sophisticated bivariate long-run asymmetries are present in the prices of the fuel sector and that those price reactions depend on whether the oil price increases or decreases, on the stage of the production, the distribution chain as well as on the period considered.
\end{abstract}

JEL classification: B23, C24, C52, D43, L13, L71.

Keywords: Gasoline Price Asymmetries, Threshold-ECM models, Double-Threshold-ECM models, Logistic-STAR Models, Nonlinear Error Correction Models, Rockets and Feathers.

\footnotetext{
${ }^{1}$ The Corresponding author holds an UC3M-Chair for internationalization and acknowledges financial support from the Spanish Ministry of Innovation and Science ECO2012-36559 and María de Maeztu Grant MDM 2014-0431.
} 


\section{Introduction}

Price determination in the fuel market has been a controversial issue during the last decades. In most economies, the fuel sector has been accused of having high market power and, as a result, of carrying non-competitive practices. Particularly, it has been argued that fuel prices suffer from asymmetric price rigidity. When input costs increase, output price raises faster; however, when input costs decrease, output prices adjust more slowly. This phenomenon is called "asymmetric price transmission", informally known as "rockets and feathers". The existence of these asymmetries is undesirable since it can be detrimental for consumers and it can lead to efficiency losses.

Competition authorities, especially with regard to the retail gasoline market, have repeatedly targeted the Spanish automotive fuel sector. On the one hand, at national level, the $\mathrm{CNMC}^{2}$ has pointed out the lack of competition in the sector. With this regard, the CNMC has fined Repsol, Cepsa and BP for fixing prices in their petrol stations for several times (CNMC, 2015). On the other hand, at supranational level, the European Commission presented its concerns about some practices such as the Repsol vertical agreements, accused of practicing exclusive dealing contracts (European Commission, 2016).

Asymmetric price transmission has been studied for several markets across the world but it has been focused on the fuel market. In the case of US, different studies deal with this topic. The most common way to tackle the presence of the rockets and feathers phenomenon is following the pioneering work of Borenstein et al. (1997). Using weekly data for different states during 1986-1990, they create an Autoregressive Distributed Lag (ARDL) and an Error Correction Model (ECM). The results of these empirical models show that the adjustments of spot and retail gasoline prices to changes in weekly crude oil prices are asymmetric. However, when using daily data for the same period, Bachmeier and Griffin (2003) detect no asymmetries in price transmission. Balke et al. (1998), found evidence for a persistent asymmetry through an ECM during 1987-1997. Deltas (2008) showed that retail gasoline prices respond faster to wholesale price increases than decreases. He suggests that sticky prices and response asymmetries are consequences of retail market power. If market power leads to higher price-cost margins, it is more likely that their price dynamics tend to be beneficial rather than detrimental for their profits. Furthermore, his results are consistent with different forecast methods, which show better accuracy for asymmetric models than the symmetric ones.

Apart from the fuel market price asymmetries, Peltzman (2000) studied the asymmetry in producer and consumer markets for 77 consumer goods and 165 producer goods with monthly data for the US. He carried out the study analysing only the products in which a unique input accounts for more than $20 \%$ of the output's value. He finds that asymmetries exist and they are persistent over time with significant error correction terms. Johnson (2002) analyses central heating oil and gasoline price responses to changes in crude spot levels for 15 North-American states. The results confirm that gasoline prices respond asymmetrically to crude oil price changes, while central heating oil reacts symmetrically.

More recent studies have investigated the "rockets and feathers" phenomenon in South America. On the one hand, Mercuri (2001) demonstrates price asymmetries in the

\footnotetext{
${ }^{2}$ CNMC: Comisión Nacional de los Mercados y la Competencia (Spanish National Competition Authority).
} 
Argentinean fuel market from 1993 until 2001. The paper measures the speed of adjustment of different fuels to changes in crude oil prices. In order to do so, they construct a cumulative adjustment function. Mercuri argues how detrimental is this asymmetric behaviour for consumers and connects the asymmetry with potential noncompetitive clauses. On the other hand, Balmaceda (2008) studies the asymmetry price transmission for the case of Chile, where there is a unique refined public firm (ENAP), which belongs to the state. Instead of using time-series, a panel of weakly data with several service stations over time is applied. This analysis shows that the best model to study the asymmetry is an error correction model. Under this method, the rockets and feathers theory is met. Additionally, the study reveals that independently of the margins and geographical differentiation of service stations, the asymmetry in prices remains the same.

With regard to Europe, there are several studies as well. Bacon's (1991) work is known for being one of the pioneering researches in this topic introducing the term "rockets and feathers". Bettendorf et al (2003) analyses the retail price adjustments in the Dutch gasoline market for the 1996-2001 period. It estimates an asymmetric ECM on weekly price changes. The paper is made up of five different datasets, one for each working day. Results demonstrate that finding symmetric or asymmetric price movements depend on the day for which the prices are collected. Six years later, Bettendorf et al (2009) address the analysis for the Dutch retail gasoline market by using an Exponential Generalized Autoregressive Conditional Heteroscedasticity (EGARCH) model. The paper shows that the volatility process is not symmetric: a negative shock to the retail price has a lower impact on the variance of the retail price than a positive shock. Galeotti et al (2003) examines the adjustments of the retail price of gasoline when a shock to crude oil prices happens. The main contribution is that different countries are compared using a two-stage approach for the transmission mechanisms to figure out whether the asymmetry is at the refinery level, at the distribution level or at both stages, applying an ECM and bootstrapping. The study finds symmetric pricing for Germany, Italy and U.K. and asymmetric transmissions in the case of France and Spain with the single stage approach and the second stage of the two stage approach.

The Spanish case has not been widely studied. Cotín-Pillart (2008) replicates the cumulative response functions and the ECM model developed by Borenstein et al (1997) for the Spanish market during 1993-1998 and 1998-2005. For the first period, changes in spot gasoline prices are completely translated into retail price changes but in a symmetric way. Nevertheless, the second period shows asymmetric responses of retail prices to the spot price. Other studies are Jiménez and Perdiguero (2005) and Perdiguero (2010)

The main objective of this paper is to study the presence of different asymmetric price adjustment process for the Spanish fuel market from the beginning of January 2011 till the second week of April 2016. In order to do so, section 2 provides some background on the Spanish fuel market. Section 3 describes the univariate and single equation dynamic models of the price variables (stationarity, unit roots, asymmetries, nonlinear error correction models) and shows the empirical results of the long-run relationships (cointegrating relationships). Section 4 provides the main empirical results obtained by estimating the nonlinear and asymmetric models developed in Section 3. Section 5 provides alternative economic explanations of the existing fuel price asymmetries in Spain. Finally, section 6 concludes the paper with the main results and possible extensions. 


\section{The Spanish gasoline market}

\subsection{Historical background}

Unlike other European economies, the Spanish petrol market was operated through a government monopoly called CAMPSA ${ }^{3}$, from 1927 until 1992. During that period, the total number of petrol stations in Spain was much lower than in most European countries ${ }^{4}$. CAMPSA was a vertically integrated company, which managed the distribution of fuel and set the final selling prices under the orders from the government.

In 1985, the liberalization and privatization processes began with the 5/1985 Royal Decree. This change in the legislation made possible the creation of a parallel network of private petrol stations. Thereafter, the 4/1988 and 4/1991 Royal Decrees reduced the distances between service stations, with the aim of increasing the competition levels in the sector.

From 1992 onwards, the liberalization process has become more important with the $34 / 1992$ law, which approved the freedom of this economic activity in all its segments. One year later, the authorities got rid of the minimum distances law. In 1998, the liberalization of petrol prices arrived together with the free access to the oil product logistical network, $\mathrm{CLH}^{5}$.

\subsection{Characteristics of the market}

The fuel market is a complex sector made up of several stages from the extraction of crude oil until the production, distribution and sale of gasoline to final consumers (see Figure 1). One of the main characteristics of the fuel market is that it is highly concentrated, especially in Spain (see Table 1). To measure the concentration, this paper makes use of the Herfindahl-Hirschman Index (HHI). According to the US regulation, having more than 1800 would imply that the market is concentrated. The Spanish HHI of service stations in 2012 was 2105, which is lower than previous recorded years. For instance, in 2009, the Spanish HHI had more than 2500 points, the second highest within Europe, only surpassed by Portugal. In the same vein, the Lerner index ${ }^{6}$ is assumed to be high for most of the firms acting in this market due to inelastic demand for fuel products and high firm's market share of Repsol, Cepsa and BP.

\footnotetext{
${ }^{3}$ CAMPSA: Compañía Arrendataria del Monopolio de Petróleos Sociedad Anónima.

${ }^{4}$ Correlje (1994) makes a comparison between the number of petrol stations in Spain and other EU countries. In 1985, there were 0,93 service stations per 100km in Spain, 6,4 in France, 8,7 in United Kingdom, 12 in Italy and 22 in the Netherlands.

${ }^{5}$ CLH: Compañía Logística de Hidrocarburos.

${ }^{6}$ The Lerner Index is a measure of market power, which is positively related to the firm's market share and negatively related to the elasticity of market demand: $L=\frac{-1}{E_{d}}$.
} 
Figure 1: Price formation along the production-distribution chain

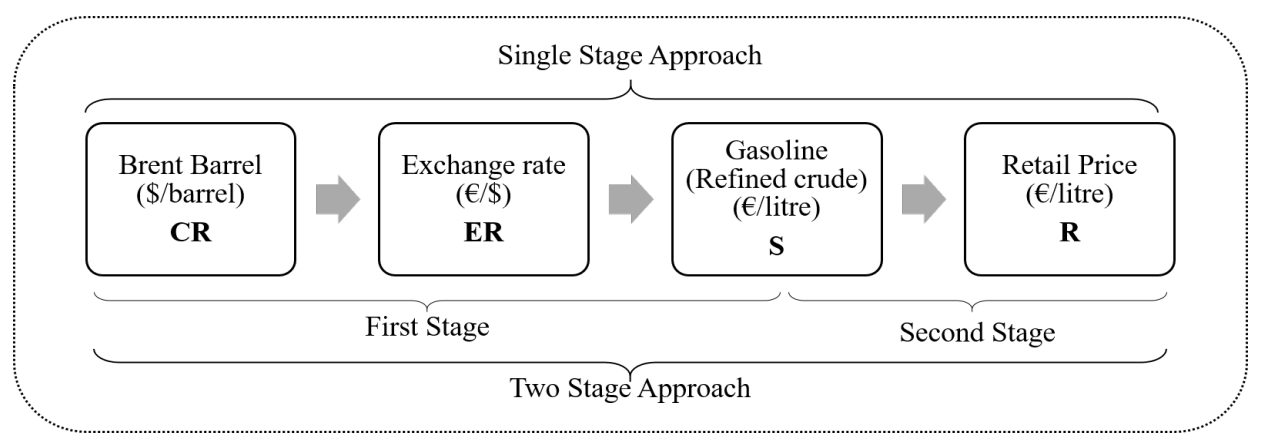

Note. The single stage approach shows how final retail prices $(R)$ are related with crude oil prices (CR). However, the two-stage methodology divides the price transmission in two stages. The first stage associates spot gasoline prices (S) with crude oil prices given by the Brent Barrel (CR). The second stage described the relationship between retail prices $(R)$ and spot gasoline prices $(S)$.

Table 1: Market shares of Spanish fuel companies in 2012

\begin{tabular}{|c|c|c|}
\hline \multirow{2}{*}{$\begin{array}{l}\text { Operators in the Spanish Market } \\
\text { Companies with refining industry }\end{array}$} & Share of service stations (\%) & Sales quota of service stations (\%) \\
\hline & & \\
\hline \multicolumn{3}{|l|}{ REPSOL, CEPSA and BP } \\
\hline Total & $60 \%$ & $63 \%$ \\
\hline \multirow{2}{*}{\multicolumn{3}{|c|}{$\begin{array}{l}\text { Companies without refining industry } \\
\text { DISA, GALP, MEROIL, ESERGUI, SARAS, } \\
\text { independents and others }\end{array}$}} \\
\hline & & \\
\hline Total & $37 \%$ & $28 \%$ \\
\hline \multirow{2}{*}{\multicolumn{3}{|c|}{$\begin{array}{l}\text { Service stations own by hypermarkets } \\
\text { CARREFOUR, SABECO, EROSKI } \\
\text { ALCAMPO and others }\end{array}$}} \\
\hline & & \\
\hline Total & $3 \%$ & $9 \%$ \\
\hline Herfindahl-Hirschman Index & 2105 & 2258 \\
\hline
\end{tabular}

Source: Comisión Nacional de los mercados y la competencia.

The main leader is Repsol $\mathrm{CPP}^{7}$, which is a Spanish company that belongs to the Repsol-YPF ${ }^{8}$ group. It owns more than 4500 service stations in Spain, Portugal and Italy. The firm is vertically integrated across the whole supply and distribution chain. It covers from the refining process until the fuel distribution to final consumers through its own service stations and agreements with other operators. COCO, CODO, DODO, tenancy and usufruct contracts ${ }^{9}$ form part of the notified agreements, investigated by the European Commission for its potential non-competitive clauses. European Commission (2001) argued that some of these notified agreements are long-term exclusive dealing contracts, which could give rise to foreclosure or lock-in effects.

Another important aspect of the fuel market is related to the transport of these products. If the fuel transportation industry is not competitive enough, the fuel distribution costs could increase, leading to foreclosure effects. The most efficient middle- and long- distance transport mean in Spain is the oil pipeline, which market is a natural monopoly. During a long period of time, it has been regarded as the bottleneck of the liberalized Spanish oil market. Nonetheless, there have been diverse changes in

\footnotetext{
${ }^{7}$ Repsol CPP: Repsol Comercial de Productos Petrolíferos.

${ }^{8}$ Repsol YPF: Repsol Yacimientos Petrolíferos Fiscales.

${ }^{9} \mathrm{COCO}$ (Company Owner-Company Operated), CODO (Company Owner-Dealer Operator) and DODO (Dealer Owner-Dealer Operators). In 2012, it was found COCO contracts to offer gasoline at the highest prices (Comisión Nacional de Energía, 2012).\}
} 
the regulation to address this problem. As a result, the Spanish pipeline market is in hands of CLH. To avoid possible discriminatory transportation costs, the company is owned by fuel distributors. In this way, new retailers can have access to the transport market in the same conditions as the old ones. However, following the reasoning of Adams and Brook (1983), this measure can still have a foreclosure effect since CLH can establish a high minimum volume to enter the transport industry together with disproportional quality control that only big companies can guarantee.

\section{Methodology}

\subsection{Data}

In order to study the potential asymmetric price transmissions in the Spanish fuel market, weekly data from the first week of January 2011 until the second week of April 2016 is used, which involves 277 observations. The variables employed in this paper are the price of crude oil (CR), the $€ / \$$ exchange rate (ER), the gasoline spot price (S) and the pre-tax retail price of 95 octane gasoline (RS for Spanish retail price). The abbreviations of the variables in capital letters refer to the series in levels and lowercase letters represent the series in logarithms(cr, er, s and rs).

Figure 2.1: Variables representation of the production-distribution chain

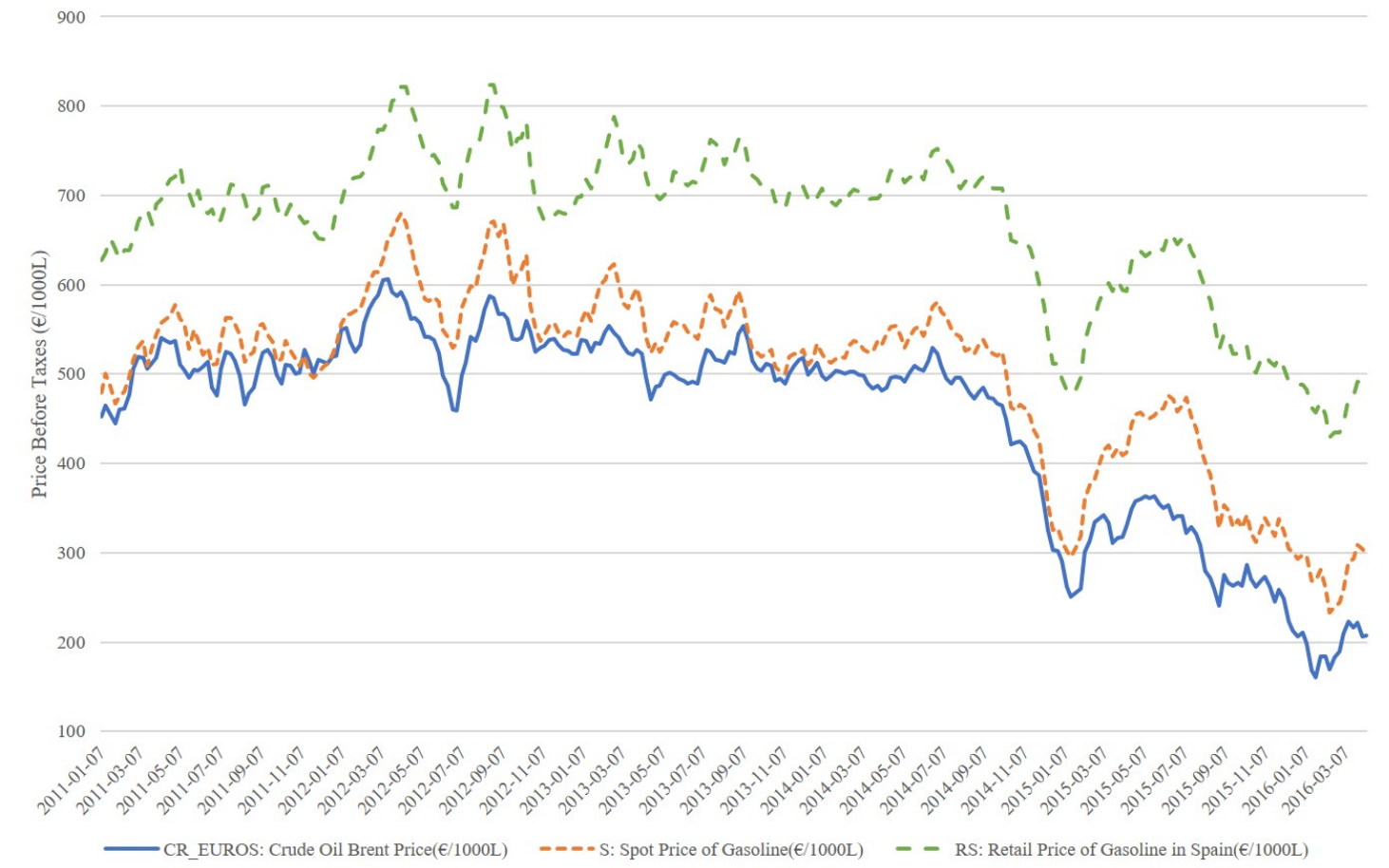

Note. The intuition that variables are cointegrated is shown in this graph. It is observed that series move together over time. Therefore, it is likely that they share a common trend.

For crude oil prices, the weekly Europe Brent Spot Price FOB ( $\$$ per barrel) from the US Energy Information Administration (EIA) is used, transformed into $\$ / 1000 \mathrm{~L}$. The exchange rate is obtained from the FRED. To measure the gasoline spot price, the 
approximation ( $€ /$ tons) of the CNMC is applied ${ }^{10}$. The pre-tax retail price chosen is an average of the 95 octane gasoline prices ( $€ /$ litre) provided by the CNMC as well. The last two variables are transformed ${ }^{11}$ into $€ / 1000 \mathrm{~L}$.

The variables in the Figure 2.1 show the relationship between crude oil prices and gasoline prices at different stages of the production-distribution chain for the 95-octane gasoline. The difference between $S$ and CR_EUROS can be a proxy of the margin in the first stage of the production-distribution chain, whereas the difference between RS and $S$ are an approach to the margin in the second stage. This figure shows that there is a change in the series around the second half of 2014. During the first decade of the 21st century, prices sharply increased due to higher demands of emerging markets like China, India or Brazil, which were rapidly growing. However, from 2010 onwards, some of these economies slowed down its growth, reducing their demands of oil and therefore, pushing prices downwards. Apart from this fact, there were other factors contributing to the 2014 drop in oil prices. Technological advances such as fracking, allowed US economy to reduce its oil imports, decreasing international oil prices even more. This together with OPEC's decision of continuing its production instead of reducing the supply, made prices fall even further. For this reason, the empirical section of this paper makes two subsamples from the 2011-2016 period. The first subsample covers from the first week of January 2011 until the last week of June 2014 (183 observations). The second one goes from the first week of July until the second week of April 2016 (94 observations).

Figure 3.2: Variables representation of the production-distribution chain in first differences of logarithms (rates of growth of prices)

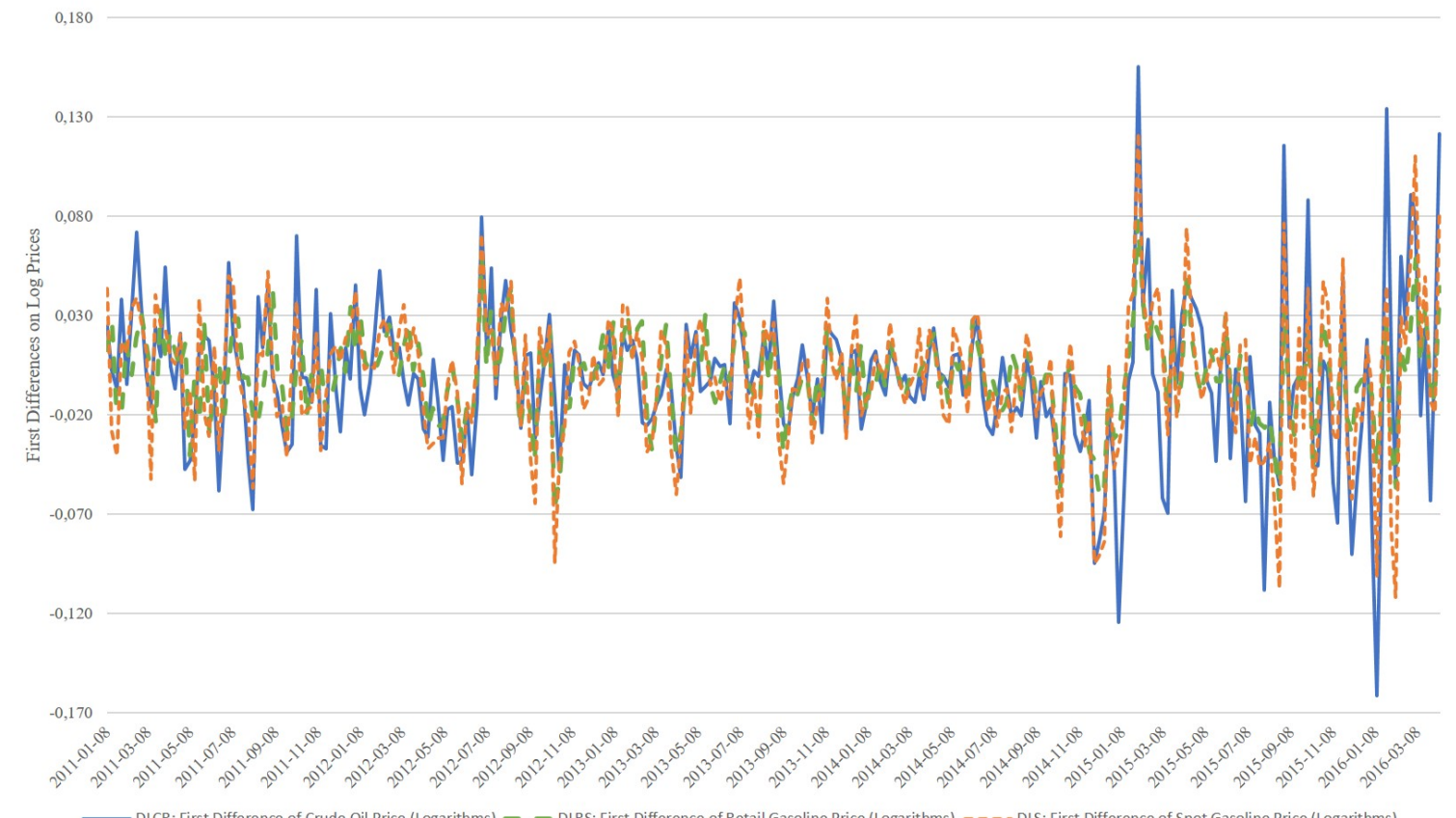

\footnotetext{
${ }^{10}$ This spot price is a compound indicator made up of $70 \%$ of Mediterranean CIF quotations and $30 \%$ of North West European CIF market quotations (Source: CNMC).

${ }^{11}$ The unit conversion of the spot price of gasoline is derived from applying the following formula: $P_{\text {gasoline }}(€ / t)=\left[P_{\text {gasoline }}(€ / \mathrm{t}) / 1000\right]^{*}\left[740\left(\mathrm{~kg} / \mathrm{m}^{3}\right) / 1000\right]{ }^{*} 1000=P_{\text {gasoline }}(€ / 1000 \mathrm{~L})$.
} 


\subsection{Descriptive statistics}

Descriptive statistics give us a quick intuition about whether the variables of interest are potentially symmetric or asymmetric.

Univariate statistics for the first differences of the series in levels and in logarithms are represented in Table 2 and Table 3 respectively. We evaluate if the change in prices is normally distributed (Gaussian distribution) or not. Jarque-Bera tests shows how the sample data do not always match the skewness and kurtosis of the Normal distribution. In most of the cases where variables are not normally distributed, the median is greater than the mean and very asymmetric and the skewness is negative meaning that their distributions are left-skewed. Therefore, the mass of the distribution is concentrated on the right of the histogram axis and the left tail is fatter.

More asymmetries are visible before the sharp drop of crude oil prices in 2014 than afterwards.

Table 2: Univariate Statistics-First Differences in Levels

\begin{tabular}{|c|c|c|c|c|c|c|}
\hline & & & $\Delta C R$ & $\Delta S$ & $\Delta R S$ & $\Delta E R$ \\
\hline \multirow{15}{*}{ Period } & \multirow{5}{*}{$\begin{array}{l}2011- \\
2016\end{array}$} & Mean & -1.197 & -0.5612 & -0.4400 & 0.0004 \\
\hline & & Median & -1.320 & 1.123 & 0.0000 & 0.0006 \\
\hline & & Skewness & 0.2309 & -0.322 & -0.1688 & 0.0809 \\
\hline & & Kurtosis & 3.4155 & 3.229 & 3.517 & 3.9813 \\
\hline & & $\begin{array}{l}\text { Jarque- } \\
\text { Bera } \\
\text { (p-value) }\end{array}$ & $\begin{array}{l}4.423 \\
(0.1095)\end{array}$ & $\begin{array}{l}5.365^{*} \\
(0.0683)\end{array}$ & $\begin{array}{l}4.371 \\
(0.1123)\end{array}$ & $\begin{array}{l}11.3356^{* * *} \\
(0.0034)\end{array}$ \\
\hline & \multirow{5}{*}{$\begin{array}{l}2011- \\
2014\end{array}$} & Mean & 0.5370 & 0.4974 & 0.6263 & -0.0001 \\
\hline & & Median & -0.2515 & 2.908 & 1.000 & 0.0000 \\
\hline & & Skewness & 0.1510 & -0.5068 & -0.2938 & 0.1832 \\
\hline & & Kurtosis & 3.381 & 3.458 & 3.705 & 3.6057 \\
\hline & & $\begin{array}{l}\text { Jarque- } \\
\text { Bera } \\
\text { (p-value) }\end{array}$ & $\begin{array}{l}1.792 \\
(0.408)\end{array}$ & $\begin{array}{l}9.387 * * * \\
(0.0091)\end{array}$ & $\begin{array}{l}6.389^{* *} \\
(0.0409)\end{array}$ & $\begin{array}{l}3.8004 \\
(0.1495)\end{array}$ \\
\hline & \multirow{5}{*}{$\begin{array}{l}2014- \\
2016\end{array}$} & Mean & -4.733 & -2.717 & -2.617 & 0.0015 \\
\hline & & Median & -4.559 & -4.164 & -3.000 & 0.0021 \\
\hline & & Skewness & 0.3923 & 0.0327 & 0.0906 & -0.1542 \\
\hline & & Kurtosis & 3.716 & 3.107 & 3.425 & 3.688 \\
\hline & & $\begin{array}{l}\text { Jarque- } \\
\text { Bera } \\
\text { (p-value) }\end{array}$ & $\begin{array}{l}4.421 \\
(0.1096)\end{array}$ & $\begin{array}{l}0.0617 \\
(0.9695)\end{array}$ & $\begin{array}{l}0.838 \\
(0.6575)\end{array}$ & $\begin{array}{l}2.231 \\
(0.3275)\end{array}$ \\
\hline
\end{tabular}


Table 3: Univariate Statistics-First Differences in Logarithms

\begin{tabular}{|c|c|c|c|c|c|c|c|c|c|}
\hline & & & $\Delta c r$ & $\Delta s$ & $\Delta r s$ & $\Delta e r$ & $e$ & $v$ & $u$ \\
\hline \multirow{15}{*}{ Period } & \multirow{5}{*}{$\begin{array}{l}2011- \\
2016\end{array}$} & Mean & -0.0029 & -0.0014 & -0.0007 & 0.0005 & -0.0006 & 0.00039 & 0.0000 \\
\hline & & Median & -0.0019 & 0.0028 & 0.0000 & 0.0007 & 0.0003 & 0.0035 & 0.0037 \\
\hline & & Skewness & 0.2156 & -0.2345 & -0.1202 & 0.0908 & 0.1346 & -0.6866 & -0.3559 \\
\hline & & Kurtosis & 6.209 & 4.234 & 3.797 & 3.6298 & 3.1653 & 3.1780 & 2.8102 \\
\hline & & $\begin{array}{c}\text { Jarque- } \\
\text { Bera } \\
\text { (p-value) }\end{array}$ & $\begin{array}{l}120.156 * * * \\
(0.0000)\end{array}$ & $\begin{array}{l}19.975 * * * \\
(0.0000)\end{array}$ & $\begin{array}{l}7.9453 * * \\
(0.0188)\end{array}$ & $\begin{array}{l}4.9240 * \\
(0.0852)\end{array}$ & $\begin{array}{c}1.1441 \\
(0.5643)\end{array}$ & $\begin{array}{c}21.972 * * * \\
(0.0000)\end{array}$ & $\begin{array}{l}6.2185 * * \\
(0.0446)\end{array}$ \\
\hline & \multirow{5}{*}{$\begin{array}{l}2011- \\
2014\end{array}$} & Mean & 0.0008 & 0.0009 & 0.0009 & -0.0002 & 0.0001 & 0.0000 & -0.0014 \\
\hline & & Median & -0.0003 & 0.0051 & 0.0013 & 0.0000 & 0.0023 & 0.0027 & 0.0035 \\
\hline & & Skewness & 0.2076 & -0.4295 & -0.2514 & 0.2218 & -0.1721 & -0.3378 & -0.7098 \\
\hline & & Kurtosis & 3.557 & 3.166 & 3.531 & 3.829 & 2.4291 & 2.5116 & 3.109 \\
\hline & & $\begin{array}{c}\text { Jarque- } \\
\text { Bera } \\
\text { (p-value) }\end{array}$ & $\begin{array}{l}3.662 \\
(0.1601)\end{array}$ & $\begin{array}{l}5.806 * \\
(0.0548)\end{array}$ & $\begin{array}{c}4.057 \\
(0.1315)\end{array}$ & $\begin{array}{l}6.709 * * \\
(0.0349)\end{array}$ & $\begin{array}{c}3.369 \\
(0.1854)\end{array}$ & $\begin{array}{l}5.2991 * \\
(0.0706)\end{array}$ & $\begin{array}{c}15.3755^{* * *} \\
(0.0004)\end{array}$ \\
\hline & \multirow{5}{*}{$\begin{array}{c}2014- \\
2016\end{array}$} & Mean & -0.0104 & -0.0061 & -0.0042 & 0.0019 & -0.0015 & 0.0000 & 0.0034 \\
\hline & & Median & -0.0131 & -0.0086 & -0.0051 & 0.0023 & -0.0024 & -0.0002 & 0.0049 \\
\hline & & Skewness & 0.5168 & 0.0820 & 0.1748 & -0.1590 & 0.2945 & 0.3604 & -0.0037 \\
\hline & & Kurtosis & 4.358 & 3.430 & 3.587 & 3.448 & 2.666 & 3.4089 & 2.228 \\
\hline & & $\begin{array}{c}\text { Jarque- } \\
\text { Bera } \\
\text { (p-value) }\end{array}$ & $\begin{array}{l}11.409 * * * \\
(0.0033)\end{array}$ & $\begin{array}{l}0.8298 \\
(0.6603)\end{array}$ & $\begin{array}{c}1.830 \\
(0.4003)\end{array}$ & $\begin{array}{c}1.185 \\
(0.5528)\end{array}$ & $\begin{array}{c}1.795 \\
(0.4075)\end{array}$ & $\begin{array}{c}2.6906 \\
(0.2604)\end{array}$ & $\begin{array}{c}2.351 \\
(0.3085)\end{array}$ \\
\hline
\end{tabular}

Note. The variables $e, v$ and $u$ represent the residuals obtained when estimating the cointegration equations (1) to (3) of section 3.3 by FM-OLS.

\subsection{Nonlinear and Asymmetric Dynamic Models with Cointegrated variables}

As was mentioned in section 2 , the fuel market is a complex sector made up of several stages from the extraction of crude oil until the production, distribution and sale of gasoline to final consumers. Therefore, it is crucial to study not only whether asymmetries exist but also in which segment of the market they occur.

The vast majority of the rockets and feathers investigations developed an ECM methodology due to the presence of cointegration between downstream and upstream prices.

Asymmetries in the long run (LR) equilibrium errors:

$$
p_{t}=p_{t}^{*}+e c m_{t}=E\left(p_{t} / x_{t}, \alpha\right)+e c m_{t}=\alpha_{0}+\alpha_{x}^{\prime} x_{t}+e c m_{t}
$$

The variables $p_{t}$ and $x_{t}$ are $\mathrm{I}(1)$ and the equilibrium error term ecm $\mathrm{t}_{\mathrm{t}} \mathrm{I}(0)$, therefore the variables are cointegrated. If $\mathrm{ecm}_{\mathrm{t}}>0\left(\mathrm{ecm}_{t}^{+}\right)$this means that the actual price $\mathrm{p}_{\mathrm{t}}$ is above the expected long run equilibrium price $E\left(p_{t} / x_{t}, \alpha\right)=\alpha_{0}+\alpha^{\prime}{ }_{x} x_{t}$ and future prices should decrease to compensate the disequilibrium. When $\mathrm{ecm}_{\mathrm{t}}<0\left(\mathrm{ecm}_{t}^{-}\right)$the actual price $p_{t}$ is below the expected long run equilibrium price and we expect future prices to increase to correct the disequilibrium.

We also would like to check if the adjustment to the cointegrating errors $\left(e^{-1 m_{t-1}}\right)$ is symmetric or asymmetric around the equilibrium (equal to 0). For symmetry, we expect the percentage number of positive ecm $\mathrm{t}_{\mathrm{t}-1}$ values (prices $\mathrm{p}_{\mathrm{t}}$ higher than the expected long run value of the crude oil) to be close to the percentage number of negative values of $\mathrm{ecm}_{\mathrm{t}-1}$ (prices $\mathrm{p}_{\mathrm{t}}$ lower than the expected long run value of the crude oil). 
Two conditions are critical to have dynamic symmetric price movements in error correction models:

a) The short run dynamics are symmetric and

b) The equilibrium correction speeds are linear and symmetric towards the equilibrium.

Equation (2) relax the above two restrictions allowing for the asymmetry to affect both the dynamics and the error correction terms $\left(\mathrm{ecm}_{\mathrm{t}-1}\right)$ in a nonlinear way. Good books reviewing nonlinear time series models and nonlinear error correction models are provided by Franses and Van Dijk (2000), Dufrénot and Mignon(2002) and Teräsvirta, Tjostheim and Granger (2010).

Nonlinear Dynamics and Bivariate Nonlinear Error Correction

$$
\Delta p_{t}=a_{0}+a_{p}(L) \Delta p_{t-1}+a_{q}(L) \Delta q_{t}+F\left(e c m_{t-1}, \Delta c r_{t}^{+}, \Delta c r_{t}, \gamma, \beta\right)\left(c_{0}+c_{r}(L) \Delta p_{t-1}+c_{m}(L) \Delta q_{t}\right)+\varepsilon_{t}
$$

However, from the empirical results obtained in this paper on oil prices, we observe linearity in the dynamics but nonlinearity affecting the error correction terms from two different sources; (i) the sign of the $\mathrm{ecm}_{\mathrm{t}-1}$ and (ii) whether the crude oil (cr) is increasing $\left(\Delta c r_{t}^{+}\right)$or decreasing $\left(\Delta c r_{t}^{-}\right)$. We have called this model a bivariate nonlinear error correction model (BNEC), equation (3).

Bivariate Nonlinear Error Correction (BNEC)

$$
\Delta p_{t}=a_{0}+a_{p}(L) \Delta p_{t-1}+a_{q}(L) \Delta q_{t}+F\left(e c m_{t-1}, \Delta c r_{t}^{+}, \Delta c r_{t}, \gamma, \beta\right)+\varepsilon_{t}
$$

Six different linear and nonlinear parameterizations of error correction models are estimated in Tables 6, Table 7 and Table 8 with linear and nonlinear equilibrium correction terms given by:

Model 1: Linear Error Correction Model (LINEAR-ECM), Engle Granger (1987),

$$
F\left(e c m_{t-1}, \Delta c r_{t}^{+}, \Delta c r_{t}, \beta\right)=\beta e c m_{t-1}
$$

Model 2: Time Varying Error Correction Model (TV-ECM)

$$
F\left(e c m_{t-1}, \Delta c r_{t}^{+}, \Delta c r_{t}, \beta\right)=\beta_{10} e c m_{t-1}+\beta_{11} e c m_{t-1} \Delta c r_{t}
$$

Model 3. Threshold Error Correction Model (T-ECM), Granger and Lee (1989) and Escribano (1986),

$$
F\left(e c m_{t-1}, \Delta c r_{t}^{+}, \Delta c r_{t}, \beta\right)=\beta_{1} e c m_{t-1}^{+}+\beta_{2} e c m_{t-1}^{-}
$$


Model 4: Momentum Error Correction Model (M-ECM), Enders and Granger (1998), Escribano and Granger (1998) and Escribano and Pfann(1998),

$$
F\left(e c m_{t-1}, \Delta c r_{t}^{+}, \Delta c r_{t}^{-}, \beta\right)=\beta_{1} e c m_{t-1} \Delta p_{t}^{+}+\beta_{2} e c m_{t-1} \Delta p_{t}^{-}
$$

Model 5: Double Threshold Error Correction Model (DT-ECM)

$F\left(e c m_{t-1}, \Delta c r_{t}^{+}, \Delta c r_{t}^{-}, \beta\right)=\beta_{11} e c m_{t-1}^{+} \Delta p_{t}^{+}+\beta_{12} e c m_{t-1}^{+} \Delta p_{t}^{-}+\beta_{21} e c m_{t-1}^{-} \Delta p_{t}^{+}+\beta_{21} e c m_{t-1}^{-} \Delta p_{t}^{-}$

Model 6: $4^{\text {th }}$ Order polynomial Error Correction Model (4 ${ }^{\text {th }}$ POL-ECM), Escribano (1986, 2004)

$$
\begin{aligned}
& F\left(e c m_{t-1}, \Delta c r_{t}^{+}, \Delta c r_{t}, \beta\right)=\beta_{01} e c m_{t-1}+\beta_{1} e c m_{t-1}\left(\Delta c r_{t}\right)+ \\
& +\beta_{2} e c m_{t-1}\left(\Delta c r_{t}\right)^{2}+\beta_{3} e c m_{t-1}\left(\Delta c r_{t}\right)^{3}+\beta_{4} e c m_{t-1}\left(\Delta c r_{t}\right)^{4}
\end{aligned}
$$

Decision rule to select between $H_{0}$ or $H_{00}$ : Based on Teräsvirta(1994) and Escribano and Jordá(1999, 2001) in Model 6, if the minimum p-value is obtained for rejecting the null hypothesis $H_{0}=\beta_{1}=\beta_{3}=0$ (relative to the $\mathrm{p}$-value of $\mathrm{H}_{00}$ ) then the model is logistic. However, if the minimum $\mathrm{p}$-value is obtained rejecting the null hypothesis $H_{00}=\beta_{2}=\beta_{4}=0$ (relative to the $\mathrm{p}$-value of $\mathrm{H}_{0}$ ) then the model is exponential. In fact, the empirical estimation of equation (9), at the three stages indicated in section 3.4 , the parameters $\beta_{2}$ and $\beta_{4}$ were always insignificant. Therefore, in all the oil price models estimated here, the selected smooth transition specifications are always LOGISTIC, equations (10) or (11).

Model 7: Smooth Transition Error Correction Models (LOGISTIC-ECM), Teräsvirta nd Eliasson (2001),

$$
F\left(e c m_{t-1}, \Delta c r_{t}^{+}, \Delta c r_{t}, \gamma, \beta\right)=\beta e c m_{t-1}\left(\frac{1}{1+\exp \left(-\gamma \Delta c r_{t}\right)}\right) .
$$

Model 8: Double Threshold Logistic Error Correction Models (DT-LOGISTIC-ECM)

$$
\begin{aligned}
& F\left(e c m_{t-1}, \Delta c r_{t}^{+}, \Delta c r_{t}, \gamma, \beta\right)=\beta_{1}^{+} e c m_{t-1}^{+}\left(\frac{1}{1+\exp \left(-\gamma \Delta c r_{t}\right)}\right)+ \\
& +\beta_{2}^{-} e c m_{t-1}^{-}\left(\frac{1}{1+\exp \left(-\gamma \Delta c r_{t}\right)}\right) .
\end{aligned}
$$

Similar models to equation (10) but with the possibility of affecting all the dynamic parameters are for example discussed in Teräsvirta and Eliasson (2001). 


\subsection{Long-run equilibrium prices and cointegration}

The first step towards estimating an ECM is to check the order of integration of the series to be sure if they are stationary. Table 4 shows the results of using Dickey Fuller (1979) tests for unit roots, augmented Dickey Fuller (ADF) tests where we find, as expected, that all log-variables are integrated of order one, $\mathrm{I}(1)^{12}$.

The general expression of the ADF test is, $b(L) \Delta y_{t}=\alpha_{0} t+\alpha_{1} t+\rho y_{t-1}+a_{t}$. The ADF tests the order of integration of the series where the three null hypotheses always test for $\left(\mathrm{H}_{0}: \rho=0\right)$ under different parametric specifications of the extra terms. (i): with intercept and time trend; (ii): with intercept only: (iii): with neither intercept nor trend. In all the cases, we fail to reject the null hypothesis of unit root based on the critical values of MacKinnon(1996) with non-significant trend and intercept under the null.

From the results of Table 4 we conclude that: a) we reject that oil prices are I(2) and that b) we cannot reject that all the variables are integrated of order one I(1), with no significant trend and intercept. Therefore, from now on we consider that all prices and the exchange rate are all $\mathrm{I}(1)$ and that no trend component should be needed in the cointegrating relationships.

Table 4: Augmented Dickey Fuller test

\begin{tabular}{|c|l|l|l|l|l|l|l|}
\hline & \multicolumn{1}{|c|}{ (i) } & \multicolumn{1}{|c|}{ (ii) } & \multicolumn{1}{c|}{ (iii) } & & \multicolumn{1}{c|}{ (i) } & \multicolumn{1}{c|}{ (ii) } & (iii) \\
\hline $\boldsymbol{c r}$ & -2.131 & -0.310 & -0.9999 & $r s$ & -2.585 & -1.323 & -0.4515 \\
& $(0.5256)$ & $(0.9201)$ & $(0.2844)$ & & $(0.2874)$ & $(0.6192)$ & $(0.5187)$ \\
\hline$\Delta \boldsymbol{c r}$ & -12.486 & & & $\Delta r s$ & -11.906 & & \\
& $(0.0000)$ & & & & $(0.0000)$ & & \\
\hline $\boldsymbol{s}$ & -2.550 & -1.214 & -0.6035 & er & -2.230 & -0.8768 & -0.9457 \\
& $(0.3036)$ & $(0.6688)$ & $(0.4552)$ & & $(0.4703)$ & $(0.7946)$ & $(0.3064)$ \\
\hline$\Delta \boldsymbol{s}$ & -12.419 & & & $\Delta e r$ & -13.204 & & \\
& $(0.0000)$ & & & & $(0.0000)$ & & \\
\hline
\end{tabular}

To model the segmentation of the oil market discussed before, we will focus on a twostage process: First-stage, where the potential asymmetries are transmitted from crude oil prices (cr) to gasoline spot prices (s) as shown in equation (12). The second-stage, equation (13), analyse the possible asymmetric transmission mechanism going from the gasoline spot prices (s) to the final retail gasoline prices in Spain ( $r s$ ). Equations (12) to (14) express the long-run cointegrating relationships between the upstream and downstream prices formation together with the exchange rate (er).

First-stage cointegration (upstream price relationship)

$$
s_{t}=\alpha_{0 s}+\alpha_{s 1} c r_{t}+\alpha_{2 s} e r_{t}+e_{t} .
$$

Second-stage cointegration (downstream price relationship)

$$
r s_{t}=\alpha_{0 r}+\alpha_{1 r} s_{t}+v_{t} .
$$

The single-stage approach of equation (14), obtained substituting (12) into (13), is not so transparent in the transmission of price effects since it captures, the combined

\footnotetext{
12 Further analysis supporting that all variables are $\mathrm{I}(1)$, based on the speed of decay of the autocorrelations and the evolution of the partial autocorrelations, is available upon request.
} 
effects. However, following the tradition of the literature on the rockets and feathers phenomenon, a single stage approach will also be carried out.

Single-stage cointegration

$$
r s_{t}=\alpha_{01}+\alpha_{11} c r_{t}+\alpha_{21} e r_{t}+u_{t} .
$$

Table 5: Cointegrating Equations (OLS \& FM-OLS)

\begin{tabular}{|c|c|c|}
\hline & OLS & FM-OLS \\
\hline \multicolumn{3}{|c|}{ (1) First Stage: regress spot (s) on crude (cr) and exchange rate (er) } \\
\hline Constant & $\begin{array}{l}1.137 * * * \\
(12.702)\end{array}$ & $\begin{array}{l}1.064 * * * \\
(5.905)\end{array}$ \\
\hline $\mathbf{c r}_{t}$ & $\begin{array}{l}0.8541 * * * \\
(51.443)\end{array}$ & $\begin{array}{l}0.8684 * * * \\
(25.986)\end{array}$ \\
\hline $\mathbf{e r}_{t}$ & $\begin{array}{l}1.394 * * * \\
(19.226)\end{array}$ & $\begin{array}{l}1.460 * * * \\
(10.002)\end{array}$ \\
\hline ADF (Engle-Granger test) & & $-4.923 * * *$ \\
\hline \multicolumn{3}{|c|}{ (2) Second Stage: regress retail (rs) on spot (s) } \\
\hline Constant & $\begin{array}{l}2.627 * * * \\
(80.148)\end{array}$ & $\begin{array}{l}2.615 * * * \\
(39.701)\end{array}$ \\
\hline $\mathbf{S}_{t}$ & $\begin{array}{l}0.6248^{* * *} \\
(118.09)\end{array}$ & $\begin{array}{l}0.6266^{* * *} \\
(58.919)\end{array}$ \\
\hline ADF (Engle-Granger test) & & $-4.660 * * *$ \\
\hline \multicolumn{3}{|c|}{ (3) Single Stage: regress retail (rs) on crude (cr) and exchange rate (er) } \\
\hline Constant & $\begin{array}{l}3.328 * * * \\
(44.442)\end{array}$ & $\begin{array}{l}3.262 * * * \\
(20.919)\end{array}$ \\
\hline $\mathbf{c r}_{t}$ & $\begin{array}{l}0.5365 * * * \\
(38.643)\end{array}$ & $\begin{array}{l}0.5489 * * * \\
(18.984)\end{array}$ \\
\hline $\mathbf{e r}_{t}$ & $\begin{array}{l}0.9036^{* * *} \\
(14.897)\end{array}$ & $\begin{array}{l}0.9565^{* * *} \\
(7.571)\end{array}$ \\
\hline ADF (Engle-Granger test) & & $-4.065 * * *$ \\
\hline
\end{tabular}

Note. The stars ${ }^{* * *}$, ** and * indicate significance at a 1\%, 5\% and 10\% levels, respectively. The Engle-Granger test reject he null hypothesis (no-cointegration) in all cases at $1 \%$, using MacKinnon critical values, against the alternative of stationarity. Therefore, we will consider that the residuals are I(O) and the variables cointegrated.

Given that all the variables have a unit root, are I(1), if a linear combination of them is stationary, I $(0)$, the variables are cointegrated. As shown in Table 5 , there is evidence against the residuals being I(1), meaning that series are cointegrated. These long-run relationships are consistently estimated by both OLS and FM-OLS. However, we rely on the Fully Modified Least Squares (FM-OLS) parameter estimates rather than OLS, to achieve bias reductions and to get valid efficiency ${ }^{13}$ improvements to directly test the significance of the cointegration coefficients ${ }^{14}$ of equations (12) - (14), even with nonstationary variables in the regression.

\footnotetext{
${ }^{13}$ Fully modified least squares (FM-OLS) regression yields to optimal estimates for cointegrating relationships. The method developed by Phillips and Hansen (1990) corrects for serial correlation and regressors endogeneity problems resulting from cointegration by modifying least squares estimation.

${ }^{14}$ Similar results were obtained in equations (LR.1) to (LR.3), by using the dynamic OLS estimator (DOLS) of Stock and Watson (1993) instead of the FM-OLS.
} 
The Engle-Granger (1987) cointegration tests of Table 5, were carried out to decide on the existence of long-run relationships between input price and output prices, based on the augmented Dickey-Fuller test (ADF) based on the estimated residuals $\hat{e}_{t}, \hat{v}_{t}$ and $\hat{u}_{t}$; the residuals from the cointegrating regressions, equations (12) - (14).

\section{Nonlinear and asymmetric error correction models}

According to the Granger's Representation Theorem, the presence of a cointegrating relation implies that a valid ECM exists. However, it is not clear whether the error correction adjustment (equilibrium correction) is linear as in Engle and Granger (1987) or is nonlinear/asymmetric as in Escribano (1986, 2004), Escribano and Granger (1998) and Escribano and Pfann (1998).

In this section, the different error correction models (2) to (11) are estimated. As will become clear in what follows, our results show that the main source of asymmetries are coming from the impact of the ecm(-1) terms and not from the dynamics of the autoregressive distributed lags (ARDL) variables in first differences. Therefore, we will concentrate on the results obtained estimating the nonlinear dynamic equations (3) to (11).

Table 5, includes the results of the first stage cointegrating relationship, where the spot price (s) is run as a function of the crude oil (cr) and the exchange rate (er) which generates the equilibrium errors $(\mathrm{ecm})$ that are used lagged once in Table 6.

The second column of Table 6 shows the results of the single equation linear ecm(-1) model (LINEAR-ECM) during the first stage relating the crude oil prices (cr) and the exchange rate (er) with the spot price (s). The third column allows the parameters of the ecm(-1) term to change (TV-ECM) with de rate of growth of the crude oil, this nonlinearity is significant and the model improves relative to the linear ECM in terms of the information criteria (AIC, BIC, HQ). The threshold ECM (T-ECM) is significant only with the positive ecm(-1) errors and the information criteria are worse than those of the TV-ECM. A new double threshold model (DT-ECM) is suggested where we allow the previous ecm $(-1)$ terms from the T-ECM to change also depending on whether the crude oil prices are increasing or decreasing and both are significant and the information criteria improve. The next model estimated is $4^{\text {th }}$ order polynomial in terms of the rate of growth of the crude oil prices. In order to select between a Logistic or an exponential smooth transition regression model we follow the decisions rule of Teräsvirta (1994) and Escribano and Jorda (2001).

The selected smooth transition ECM model is LOGISTIC since only the odd powers are significant in the previous $4^{\text {th }}$ order Polynomial regression. The estimation results of this Logistic (LOGIST-ECM) models are showed in the previous to the last column of Table 6 and in terms of the information criteria (BIC and $\mathrm{HQ}$ ) is the best specification of all models. This Logistic ECM model has a three dimension adjustment depending on two variables; $e^{-c m_{t-1}}$ and $\Delta c r_{t}$ (see Figure 3.1). The reaction to ecm(-1) is close to 0 when the rate of growth of the price of crude oil is negative. However, when the crude oil price increases the error correction adjustment term ecm(-1) becomes significant. 
Table 6: ECM OF THE FIRST-STAGE (in logs) from 01-2011 to 04-2016 (weekly data)

\begin{tabular}{|c|c|c|c|c|c|c|c|c|}
\hline \multicolumn{9}{|c|}{ SPOT PRICES (s) as a function of CRUDE OIL PRICES (cr) and EXCHANGE RATE (er) } \\
\hline & $\begin{array}{l}\text { LIN- } \\
\text { ECM }\end{array}$ & TV-ECM & T-ECM & M-ECM & $\begin{array}{l}\text { DT- } \\
\text { ECM }\end{array}$ & $\begin{array}{c}4^{\text {th }} \text { POL- } \\
\text { ECM }\end{array}$ & $\begin{array}{c}\text { LOGIST. } \\
\text { ECM }\end{array}$ & $\begin{array}{c}\text { DT- } \\
\text { LOGIST. } \\
\text { ECM }\end{array}$ \\
\hline \multicolumn{9}{|c|}{ LINEAR TERMS (with heteroskedasticity robust s.e) } \\
\hline Constant & -0.00 & -0.00 & 0.00 & -0.00 & 0.00 & 0.00 & -0.00 & 0.00 \\
\hline$\Delta c r_{t}$ & $0.71 * * * *$ & $0.72 * * *$ & $0.70^{* * *}$ & $0.71^{* * *}$ & $0.74 * * *$ & $0.71^{* * *}$ & $0.71 * * *$ & $0.74 * * *$ \\
\hline$\Delta c r_{t-1}$ & $-0.20 * * *$ & $-0.15 * * *$ & $-0.21 * * *$ & $-0.13^{* *}$ & $-0.22 * * *$ & $-0.13^{* *}$ & $-0.22 * * *$ & $-0.22 * * *$ \\
\hline$\Delta e r_{t}$ & $1.05 * * *$ & $1.04 * * *$ & $1.07^{* * *}$ & $1.08^{* * *}$ & 1.09 *** & $1.09^{* * *}$ & $1.08 * * *$ & $1.10^{* * *}$ \\
\hline$\Delta e r_{t-1}$ & $-0.28^{*}$ & & $-0.27 *$ & & $-0.27 *$ & & $-0.32 * *$ & $-0.29 * *$ \\
\hline$\Delta s_{t-1}$ & $0.30 * * *$ & $0.23 * * *$ & $0.31^{* * *}$ & $0.22 * * *$ & $0.32 * * *$ & $0.06^{* * *}$ & $0.31 * * *$ & $0.31^{* * *}$ \\
\hline$e^{e c m}$ & $-0.13 * * *$ & $-0.12 * * *$ & & & & & & \\
\hline \multicolumn{9}{|c|}{ NON-LINEAR AND ASYMMETRIC TERMS (with heteroskedasticity robust s.e) } \\
\hline$e c m_{t-1} * \Delta c r_{t}$ & & $-1.55^{* * *}$ & & & & -1.78 & & \\
\hline$e c m_{t-1} *\left(\Delta c r_{t}\right)^{2}$ & & & & & & -11.69 & & \\
\hline$e c m_{t-1} *\left(\Delta c r_{t}\right)^{3}$ & & & & & & 40.29 & & \\
\hline$e c m_{t-1} *\left(\Delta c r_{t}\right)^{4}$ & & & & & & 230.01 & & \\
\hline$e^{e c m}+m_{t-1}^{+}$ & & & $-0.21 * * *$ & & & & & \\
\hline ecm $-1-1$ & & & -0.04 & & & & & \\
\hline$e c m_{t-1} * \Delta c r_{t}^{+}$ & & & & $-2.33 * * *$ & & & & \\
\hline $\boldsymbol{e c m}_{t-1} * \Delta c r_{t}^{-}$ & & & & -0.34 & & & & \\
\hline $\mathrm{ecm}_{t-1}^{+} * \Delta c r_{t}^{+}$ & & & & & $-0.32 * * *$ & & & \\
\hline$e c m_{t-1}^{+} * \Delta c r_{t}^{-}$ & & & & & $-0.14 *$ & & & \\
\hline $\begin{array}{c}\boldsymbol{\beta e c m}_{t-1} * \\
(1 /(1+ \\
\left.\exp \left(-\gamma \Delta \boldsymbol{c r}_{t}\right)\right)\end{array}$ & & & & & & & $\begin{array}{l}\beta=-0.30^{* * *} \\
\gamma=45.5^{*}\end{array}$ & \\
\hline $\begin{array}{c}\left(\beta^{+} e^{-c m_{t-1}^{+}+}\right. \\
\left.\beta^{-} \operatorname{ecm}_{t-1}^{-1}\right) * \\
(1 /(1+ \\
\left.\exp \left(-\gamma \Delta c r_{t}\right)\right)\end{array}$ & & & & & & & & $\begin{array}{l}\beta^{+}=-0.42 * * * \\
\beta^{-}=-0.15 \\
\gamma=39.96\end{array}$ \\
\hline \multicolumn{9}{|c|}{$* * *$ significant at $1 \%, * *$ significant at $5 \%$ and $*$ significant at $10 \%$} \\
\hline \multicolumn{9}{|c|}{ GOODNESS OF FIT AND SPECIFICATION TESTS } \\
\hline R-squared & 0.70 & 0.70 & 0.70 & 0.68 & 0.71 & 0.68 & 0.71 & 0.71 \\
\hline AIC & -5.058 & -5.086 & -5.066 & -5.013 & -5.084 & -4.994 & -5.108 & -5.113 \\
\hline BIC & -4.965 & -4.993 & -4.960 & -4.920 & -4.978 & -4.876 & -5.003 & -4.994 \\
\hline HQ & -5.021 & -5.049 & -5.023 & -4.976 & -5.041 & -4.947 & -5.066 & -5.065 \\
\hline $\begin{array}{l}\text { Breusch-Godfrey } \\
\text { LM Test (p-val): } \\
\text { AR(2) }\end{array}$ & 0.582 & 0.744 & 0.119 & 0.717 & 0.127 & 0.700 & 0.774 & 0.356 \\
\hline R-squared & 0.70 & 0.70 & 0.70 & 0.68 & 0.71 & 0.68 & 0.71 & 0.71 \\
\hline
\end{tabular}

This asymmetry is clearly seen when we project the adjustments in only two dimensions in Figures 3.2 and 3.3. In particular, Figure 3.2 shows clearly that the equilibrium adjustment is active only for increasing crude oil prices but is 0 otherwise (no correction to the expected long run spot price). Finally, Figure 3.3 shows that more times is the ecm(-1) positive than negative and that the range of positive ecm(-1) error is larger than the negative ones. 
Figure 3.1: First Stage Logistic Adjustment Function

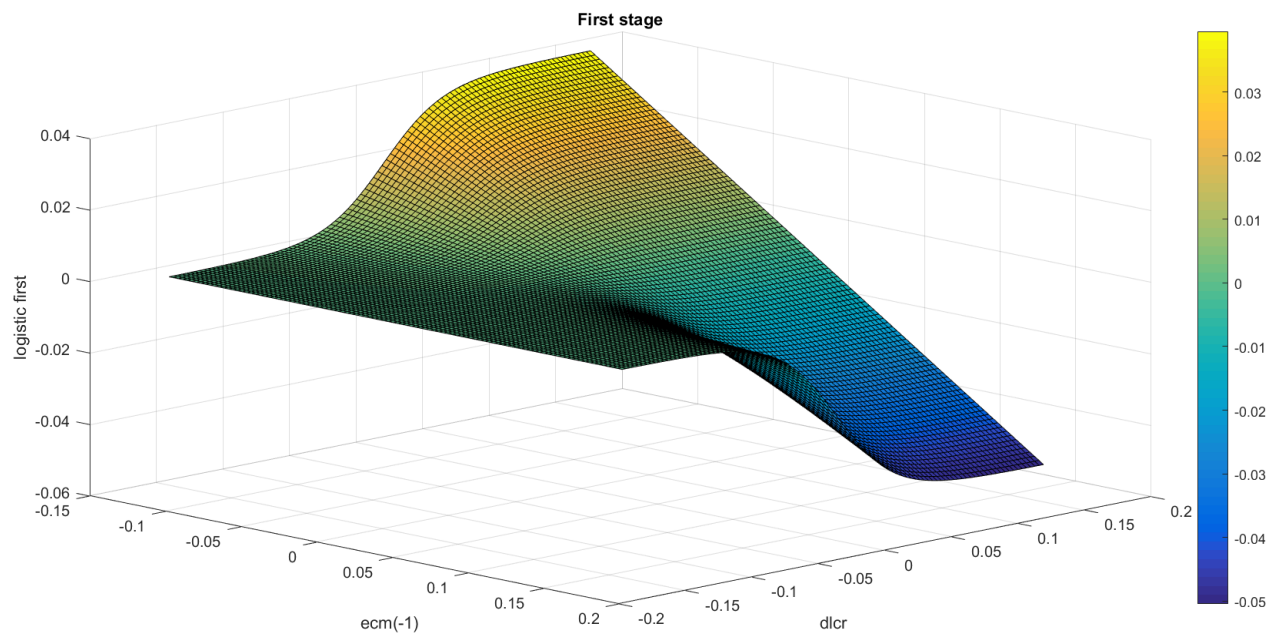

Figure 3.2: First Stage Logistic Adjustment Function Mantaining ECM(-1) fixed

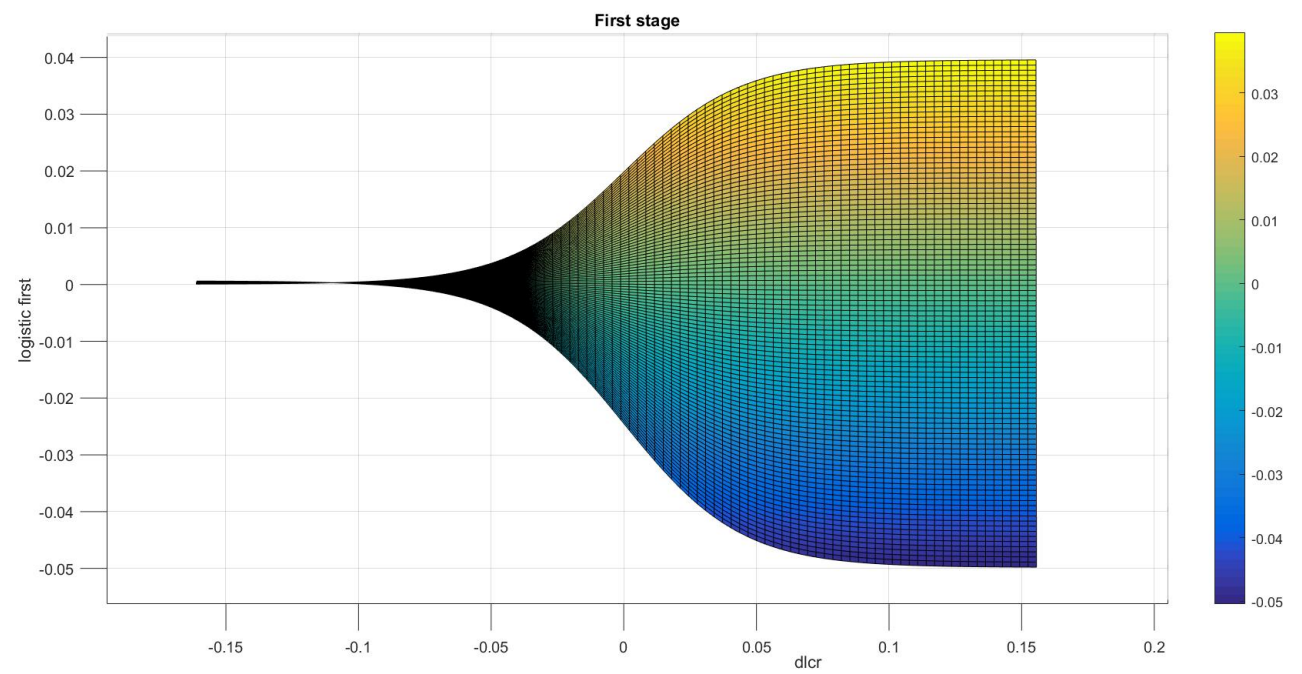

Figure 3.3: First Stage Logistic Adjustment Function Mantaining DLCR fixed

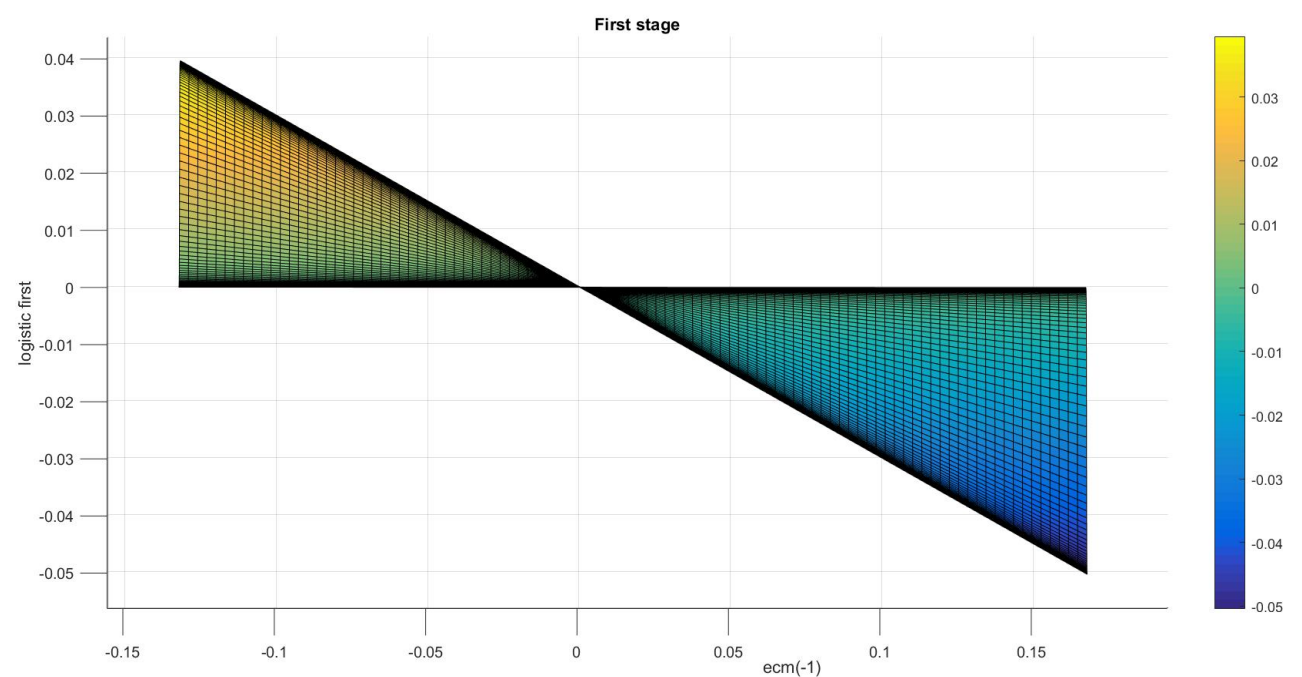


Table 7: ECM OF THE SECOND-STAGE (in logs) from 01-2011 to 04-2016 (weekly data)

\begin{tabular}{|c|c|c|c|c|c|c|c|c|}
\hline \multicolumn{9}{|c|}{ RETAIL PRICES as a function of SPOT PRICES (s) } \\
\hline & $\begin{array}{l}\text { LIN- } \\
\text { ECM }\end{array}$ & TV-ECM & T-ECM & M-ECM & $\begin{array}{c}\text { DT- } \\
\text { ECM }\end{array}$ & $\begin{array}{c}4^{\text {th }} \text { POL- } \\
\text { ECM }\end{array}$ & $\begin{array}{c}\text { LOGIST. } \\
\text { ECM }\end{array}$ & $\begin{array}{c}\text { DT- } \\
\text { LOGIST. } \\
\text { ECM }\end{array}$ \\
\hline \multicolumn{9}{|c|}{ LINEAR TERMS (with heteroskedasticity robust s.e) } \\
\hline Constant & 0.00 & 0.00 & -0.00 & 0.00 & -0.00 & 0.00 & 0.00 & -0.00 \\
\hline$\Delta \boldsymbol{s}_{t}$ & $0.48^{* * *}$ & $0.48 * * *$ & $0.48 * * *$ & $0.48 * * *$ & $0.50 * * *$ & $0.48^{* * *}$ & $0.48^{* * *}$ & $0.49 * * *$ \\
\hline$\Delta s_{t-1}$ & $-0.25 * * *$ & $0.26 * * *$ & $-0.25 * * *$ & $0.29 * * *$ & $-0.26 * * *$ & $0.31 * * *$ & $0.25 * * *$ & $0.25 * * *$ \\
\hline$\Delta \boldsymbol{s}_{t-2}$ & $0.07 * * *$ & $0.07 * * *$ & $0.07 * * *$ & $0.07 * * *$ & $0.07 * * *$ & $0.08^{* * *}$ & $0.07 * * *$ & $0.07 * * *$ \\
\hline$\Delta r_{t-1}$ & $-0.26 * * *$ & $-0.25 * * *$ & $-0.25^{* * *}$ & $-0.29 * * *$ & $-0.26^{* * *}$ & $-0.32 * * *$ & $-0.25 * * *$ & $-0.24 * * *$ \\
\hline ecm $t-1$ & $-0.13 * * *$ & $-0.14 * * *$ & & & & & & \\
\hline \multicolumn{9}{|c|}{ NON-LINEAR AND ASYMMETRIC TERMS (with heteroskedasticity robust s.e) } \\
\hline$e^{c} m_{t-1} * \Delta c r_{t}$ & & $3.06^{* *}$ & & & & $5.97 * * *$ & & \\
\hline$e^{c} m_{t-1} *\left(\Delta c r_{t}\right)^{2}$ & & & & & & -21.37 & & \\
\hline$e^{c} m_{t-1} *\left(\Delta c r_{t}\right)^{3}$ & & & & & & $-510.1 * * *$ & & \\
\hline$e_{c m} *\left(\Delta c r_{t}\right)^{4}$ & & & & & & 1941.35 & & \\
\hline $\operatorname{ecm}_{t-1}^{+}$ & & & -0.06 & & & & & \\
\hline$e^{c} m_{t-1}^{-}$ & & & $-0.18 * * *$ & & & & & \\
\hline $\boldsymbol{e c m}_{t-1} * \Delta c r_{t}^{+}$ & & & & 1.23 & & & & \\
\hline $\operatorname{ecm}_{t-1} * \Delta c r_{t}^{-}$ & & & & $5.45 * * *$ & & & & \\
\hline $\mathrm{ecm}_{t-1}^{+} * \Delta \mathrm{cr}_{t}^{+}$ & & & & & -0.09 & & & \\
\hline $\operatorname{ecm}_{t-1}^{+} * \Delta c r_{t}^{-}$ & & & & & $-0.35 * * *$ & & & \\
\hline $\begin{array}{c}\boldsymbol{\beta e c m}_{t-1} * \\
(1 /(1+ \\
\left.\exp \left(-\gamma \Delta c r_{t}\right)\right)\end{array}$ & & & & & & & $\begin{array}{l}\beta=-0.30 * * * \\
\gamma=-67.73\end{array}$ & \\
\hline $\begin{array}{c}\left(\beta^{+} \text {ecm }_{t-1}^{+}+\right. \\
\beta^{-} e^{\left.-c m_{t-1}^{-}\right) *} \\
(1 /(1+ \\
\left.\exp \left(-\gamma \Delta c r_{t}\right)\right)\end{array}$ & & & & & & & & $\begin{array}{l}\beta^{+}=-0.09 \\
\beta^{-}=-0.48^{* * *} \\
\gamma=-93.75\end{array}$ \\
\hline \multicolumn{9}{|c|}{$* * *$ significant at $1 \%, * *$ significant at $5 \%$ and $*$ significant at $10 \%$} \\
\hline \multicolumn{9}{|c|}{ GOODNESS OF FIT AND SPECIFICATION TESTS } \\
\hline R-squared & 0.78 & 0.78 & 0.78 & 0.77 & 0.78 & 0.78 & 0.78 & 0.79 \\
\hline AIC & -6.258 & -6.281 & -6.256 & -6.236 & -6.286 & -6.236 & -6.288 & -6.301 \\
\hline BIC & -6.179 & -6.188 & -6.163 & -6.143 & -6.194 & -6.117 & -6.195 & -6.195 \\
\hline HQ & -6.227 & -6.244 & -6.219 & -6.199 & -6.249 & -6.188 & -6.250 & -6.259 \\
\hline $\begin{array}{l}\text { Breusch-Godfrey } \\
\text { LM Test (p-val): } \\
\text { AR(2) }\end{array}$ & 0.123 & 0.635 & 0.212 & 0.197 & 0.631 & 0.122 & 0.523 & 0.208 \\
\hline R-squared & 0.78 & 0.78 & 0.78 & 0.77 & 0.78 & 0.78 & 0.78 & 0.79 \\
\hline
\end{tabular}

Just the opposite asymmetric behaviour is observed in the second stage when relating the spot oil prices (s) with the retail prices to compensate (rs). This is so to compensate and reduce the otherwise dramatic asymmetric price reactions that would be clearly identify as a market failure due to market power, see estimates in Table 7 and Figures 4.1 to 4.3. Notice however that in this second stage the last two columns of Table 7 logistic-ECM represent NEC models are observationally equivalent. 
Figure 4.1: Second Stage Logistic Adjustment Function

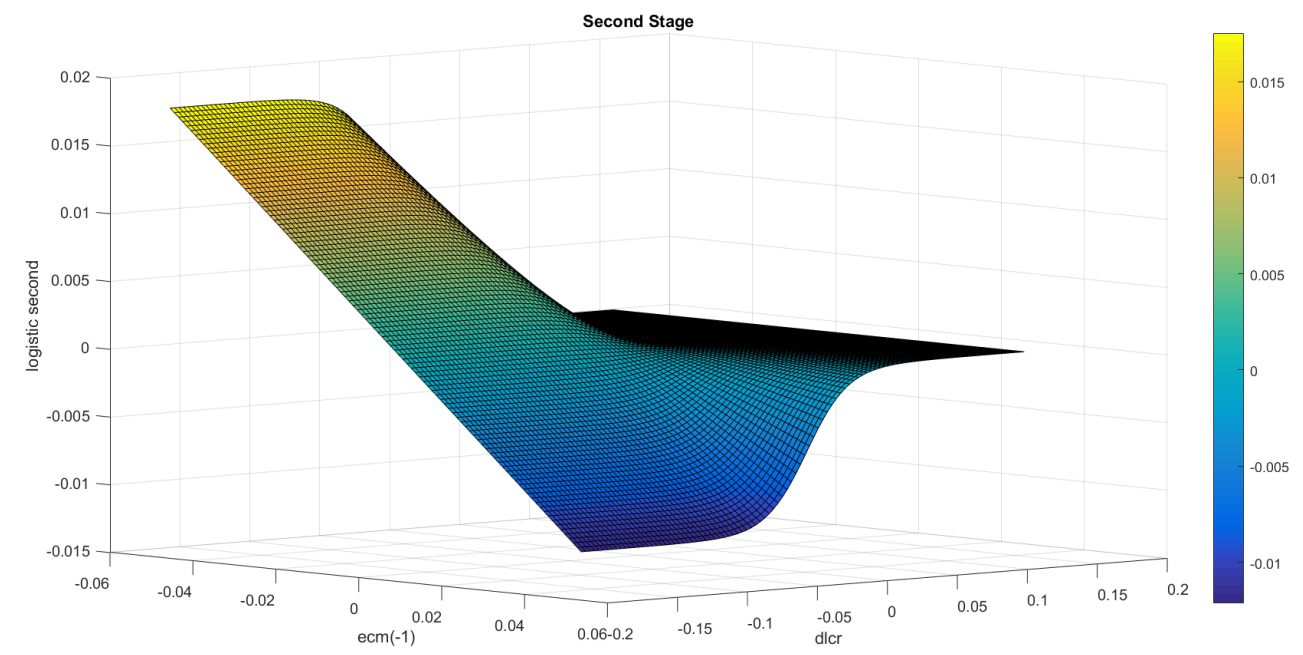

Figure 4.2: Second Stage Logistic Adjustment Function Mantaining ECM(-1) fixed

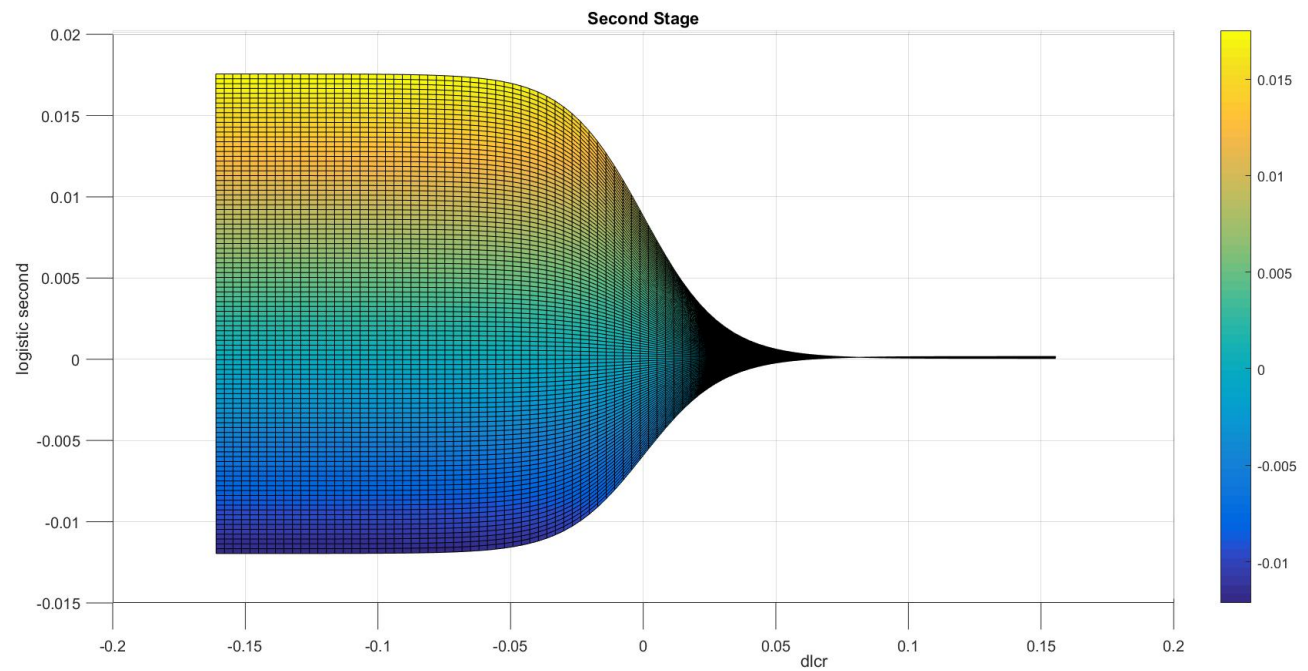

Figure 4.3: Second Stage Logistic Adjustment Function Mantaining DLCR fixed

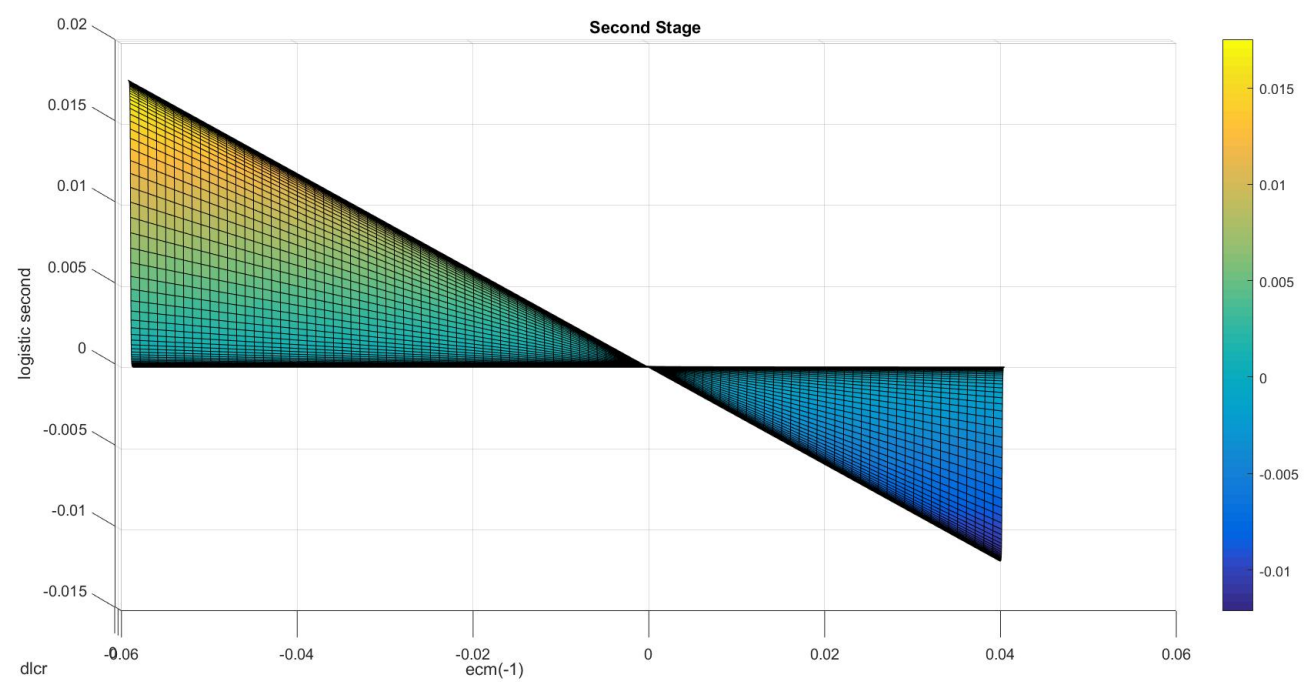


Table 8: ECM SINGLE STAGE (in logs) from 01-2011 to 04-2016 (weekly data)

\begin{tabular}{|c|c|c|c|c|c|c|c|c|}
\hline \multicolumn{9}{|c|}{ RETAIL PRICES (r) as a function of CRUDE OIL PRICES (cr) and EXCHANGE RATE (er) } \\
\hline & $\begin{array}{l}\text { LIN- } \\
\text { ECM }\end{array}$ & TV-ECM & T-ECM & M-ECM & $\begin{array}{c}\text { DT- } \\
\text { ECM }\end{array}$ & $\begin{array}{c}4^{\text {th }} \text { POL- } \\
\text { ECM }\end{array}$ & $\begin{array}{c}\text { LOGIST. } \\
\text { ECM }\end{array}$ & $\begin{array}{c}\text { DT- } \\
\text { LOGIST. } \\
\text { ECM }\end{array}$ \\
\hline \multicolumn{9}{|c|}{ LINEAR TERMS (with heteroskedasticity robust s.e) } \\
\hline Constant & 0.00 & 0.00 & 0.00 & 0.00 & 0.00 & 0.00 & 0.00 & 0.00 \\
\hline$\Delta c r_{t}$ & $0.36^{* * * *}$ & $0.36^{* * * *}$ & $0.36 * * * *$ & $0.35 * * * *$ & $0.36 * * * *$ & $0.36 * * * *$ & $0.36 * * * *$ & $0.36^{* * * *}$ \\
\hline$\Delta c r_{t-1}$ & & & & 0.06 & & & & \\
\hline$\Delta e r_{t}$ & $0.52 * * *$ & $0.54 * * *$ & $0.53 * * *$ & $0.54 * * *$ & $0.50 * * *$ & $0.53 * * *$ & $0.49 * * *$ & $0.49 * * *$ \\
\hline$\Delta e r_{t-1}$ & & & & 0.10 & & & & \\
\hline$\Delta r s_{t-1}$ & $0.18 * * *$ & $0.17 * * *$ & $0.18 * * *$ & $0.11 * * *$ & $0.20 * * *$ & $0.17 * * *$ & $0.20 * * *$ & $0.19 * * *$ \\
\hline$\Delta r s_{t-2}$ & $0.08 *$ & $0.08 *$ & $0.08 *$ & 0.06 & & $0.09 *$ & & \\
\hline$e^{e c m} m_{t-1}$ & $-0.11 * * *$ & $-0.11 * * *$ & & & & $-0.14 * * *$ & & \\
\hline \multicolumn{9}{|c|}{ NON-LINEAR AND ASYMMETRIC TERMS (with heteroskedasticity robust s.e) } \\
\hline $\operatorname{ecm}_{t-1} * \Delta c r_{t}$ & & -0.65 & & & & 0.23 & & \\
\hline $\operatorname{ecm}_{t-1} *\left(\Delta c r_{t}\right)^{2}$ & & & & & & 28.57 & & \\
\hline$e^{c} m_{t-1} *\left(\Delta c r_{t}\right)^{3}$ & & & & & & -67.94 & & \\
\hline $\operatorname{ecm}_{t-1} *\left(\Delta c r_{t}\right)^{4}$ & & & & & & -1158.42 & & \\
\hline$e \mathrm{~cm}_{t-1}^{+}$ & & & $-0.18 * * *$ & & & & & \\
\hline ecm ${ }_{t-1}^{-}$ & & & -0.06 & & & & & \\
\hline $\operatorname{ecm}_{t-1} * \Delta c r_{t}^{+}$ & & & & $-1.13 * * *$ & & & & \\
\hline $\operatorname{ecm}_{t-1} * \Delta c r_{t}^{-}$ & & & & 0.33 & & & & \\
\hline $\operatorname{ecm}_{t-1}^{+} * \Delta c r_{t}^{+}$ & & & & & $-0.25 * * *$ & & & \\
\hline $\operatorname{ecm}_{t-1}^{+} * \Delta \boldsymbol{c r}_{t}^{-}$ & & & & & $-0.18 * * *$ & & & \\
\hline $\begin{array}{c}\operatorname{\beta ecm}_{t-1} * \\
(1 /(1+ \\
\left.\exp \left(-\gamma \Delta c r_{t}\right)\right)\end{array}$ & & & & & & & $\begin{array}{l}\beta=-0.24 * * * \\
\gamma=11.93\end{array}$ & \\
\hline $\begin{array}{c}\left(\beta^{+} e^{e c m_{t-1}^{+}+}\right. \\
\left.\beta^{-} e c m_{t-1}^{-}\right) * \\
(1 /(1+ \\
\left.\exp \left(-\gamma \Delta c r_{t}\right)\right)\end{array}$ & & & & & & & & $\begin{array}{l}\beta^{+}=-0.35^{* * *} \\
\beta^{-}=-0.13^{*} \\
\gamma=11.67\end{array}$ \\
\hline \multicolumn{9}{|c|}{$* * *$ significant at $1 \%, * *$ significant at $5 \%$ and $*$ significant at $10 \%$} \\
\hline \multicolumn{9}{|c|}{ GOODNESS OF FIT AND SPECIFICATION TESTS } \\
\hline R-squared & 0.525 & 0.528 & 0.530 & 0.499 & 0.517 & 0.536 & 0.520 & 0.523 \\
\hline AIC & -5.503 & -5.502 & -5.505 & -5.426 & -5.484 & -5.496 & -5.490 & -5.490 \\
\hline BIC & -5.424 & -5.410 & -5.412 & -5.307 & -5.405 & -5.364 & -5.411 & -5.398 \\
\hline HQ & -5.472 & -5.465 & -5.468 & -5.379 & -5.452 & -5.443 & -5.458 & -5.453 \\
\hline $\begin{array}{l}\text { Breusch-Godfrey } \\
\text { LM Test (p-val): } \\
\text { AR(2) }\end{array}$ & 0.411 & 0.383 & 0.452 & 0.114 & 0.155 & 0.598 & 0.216 & 0.192 \\
\hline R-squared & 0.525 & 0.528 & 0.530 & 0.499 & 0.517 & 0.536 & 0.520 & 0.523 \\
\hline
\end{tabular}

The previously mentioned net effect becomes clear when we estimate the relation in a single stage among the crude oil prices, the exchange rate and the retail prices of gasoline. The results are in Table 8 and Figures 5.1 to 5.3. The Logistic-ECM is probably the best model now. Figure 5.1 shows a less nonlinear reaction than Figure 3.1 but still the main equilibrium adjustment occurs when the crude oil prices are increasing. 
Figure 5.1: Single Stage Logistic Adjustment Function

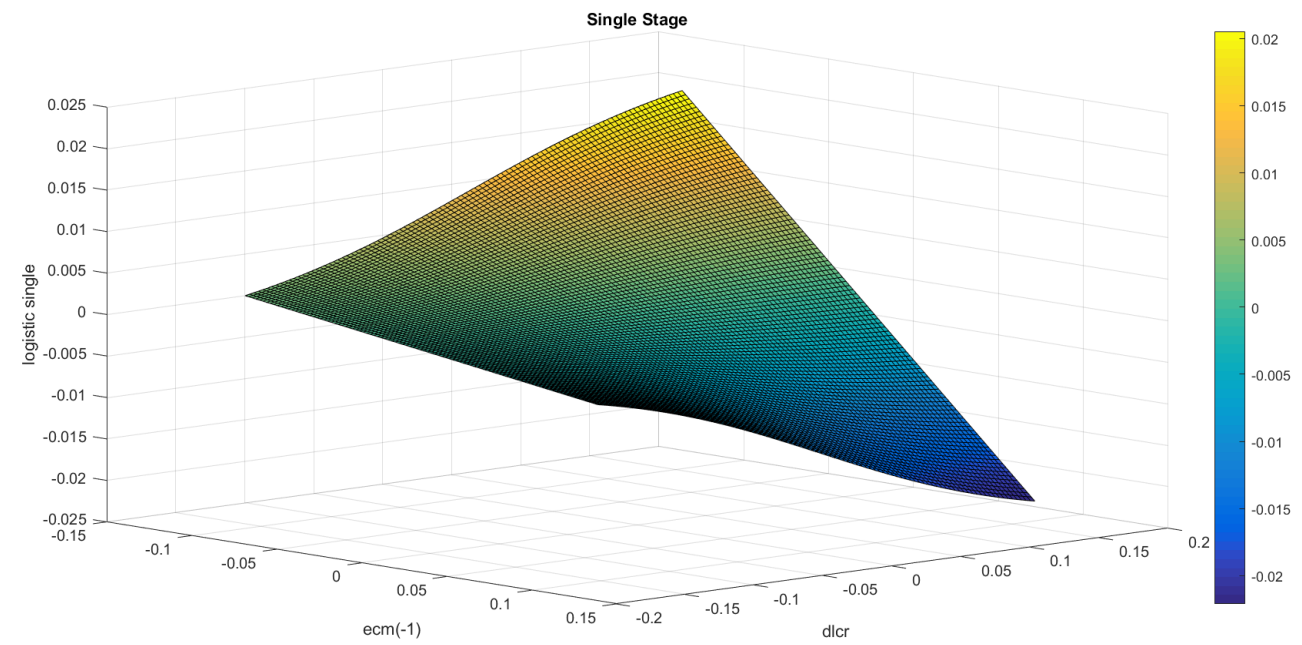

Figure 5.2: Single Stage Logistic Adjustment Function Mantaining ECM(-1) fixed

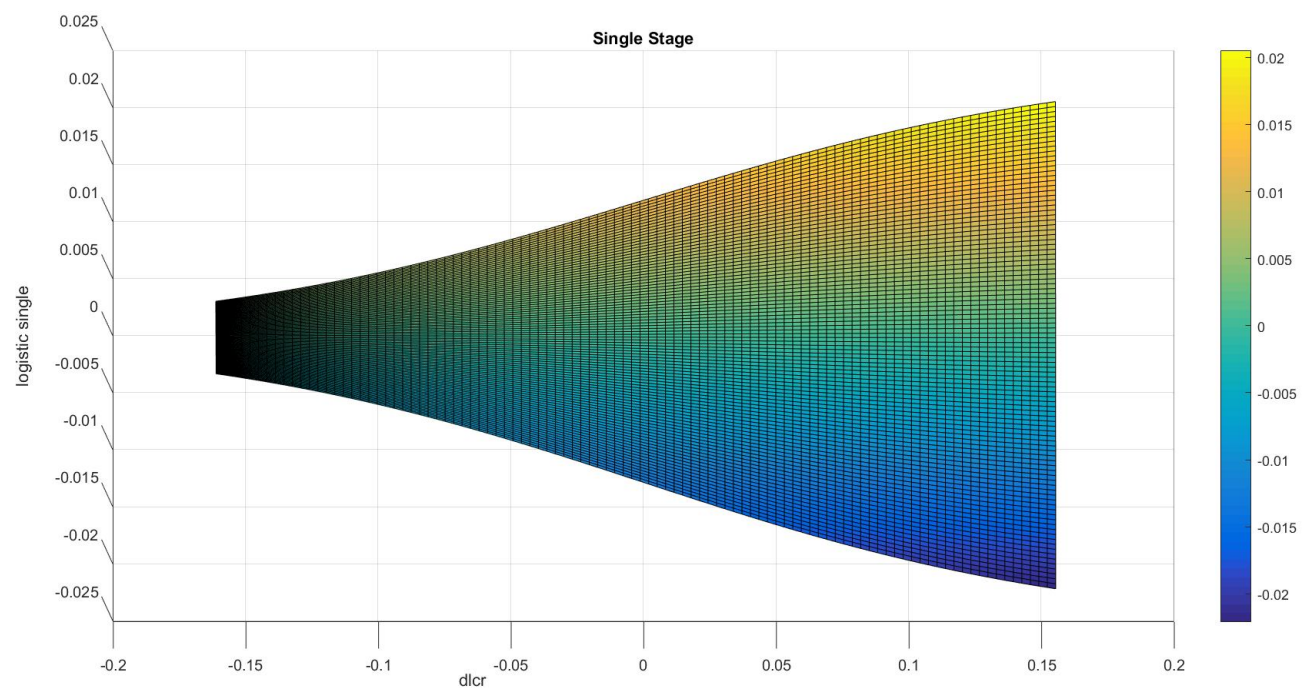

Figure 5.3: Single Stage Logistic Adjustment Function Mantaining DLCR fixed

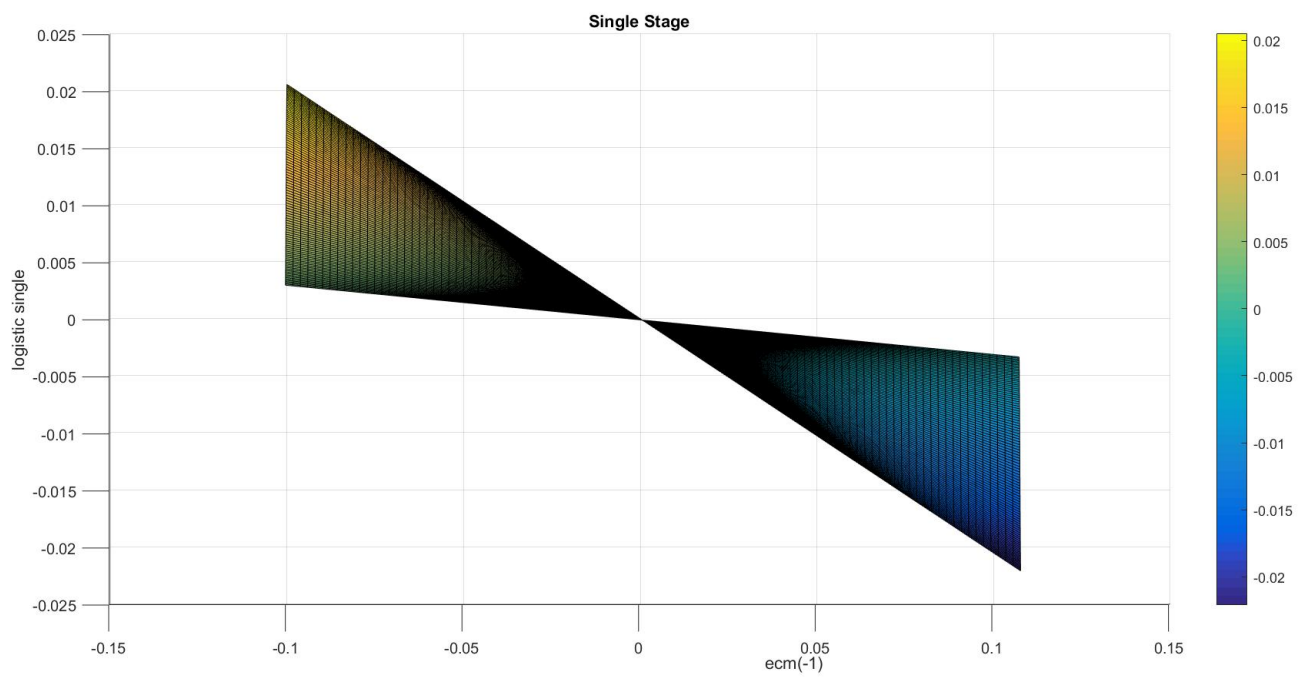


In summary, as it is shown from Table 6 and Table 8, the best models explaining the behaviour of prices in the Spanish gasoline market are the DT-ECM, LOGISTIC-ECM and DT-LOGISTIC-ECM. The outputs from these models seem to be robust since the same conclusions can be drawn from them.

Figures 3.2 and 5.2 show how prices react more to positive changes in crude oil prices than to negative ones in the first and single stage models, respectively.

With regard to the error correction term, in the first stage, Figure 3.3 exhibits that when prices are above equilibrium levels, there are more changes in the logistic function than when prices are below equilibrium. The opposite happens in the second stage (Figure 4.3). In the single stage (Figure 5.3), prices react similarly independently of the sign of the error correction term.

Consider now a detailed analysis of the best asymmetric piece-wise linear model of Table 6 to Table 8, the double threshold error correction models (DT-ECM). These models instead of considering only two possible error correction terms $\left(\mathrm{ecm}^{+}\right.$and $\mathrm{ecm}^{-}$), they allow other interactions between the error correction terms and dummy variables $\left(\mathrm{ecm}^{+} \Delta \mathrm{cr}_{t}^{+}, \mathrm{ecm}^{+} \Delta \mathrm{cr}_{t}^{-}, \mathrm{ecm}^{-} \Delta \mathrm{cr}_{t}^{+}\right.$and $\left.\mathrm{ecm}^{-} \Delta \mathrm{cr}_{t}^{-}\right)$. The dummies variables are defined as follows: $\Delta c r_{t}^{+}=1$ if $\Delta c r \geq 0$ and zero otherwise, $\Delta c r_{t}^{-}=1$ if $\Delta c r<$ 0 and zero otherwise. The threshold error correction terms are determined in the following way: $e c m_{t}^{+}=e_{t} \geq 0, v_{t} \geq 0, u_{t} \geq 0$ and $e c m_{t}^{-}=e_{t}<0, v_{t}<0, u_{t}<0$, corresponding to the 3 different long-run relations; equations (12)-(14).

First stage asymmetric double threshold error correction model (DT-ECM):

$$
\begin{aligned}
& \Delta s_{t}= \\
& \beta_{0}+\beta_{1}^{++} e c m_{t-1}^{+} \Delta c r_{t}^{+}+\beta_{2}^{+-} e c m_{t-1}^{+} \Delta c r_{t}^{-}+\beta_{3}^{-+} e c m_{t-1}^{-} \Delta c r_{t}^{+}+\beta_{4}^{--} e c m_{t-1}^{-} \Delta c r_{t}^{-}+ \\
& +\sum_{i=0}^{1} \gamma_{i} \Delta c r_{t-i}+\sum_{i=0}^{1} \delta_{i} \Delta e r_{t-i}+\phi_{1} \Delta s_{t-1}+\varepsilon_{t}
\end{aligned}
$$

Second stage asymmetric double threshold error correction model (DT-ECM)

$$
\begin{gathered}
\Delta r s_{t}=\alpha_{0}+\beta_{1}^{++} e c m_{t-1}^{+} \Delta c r_{t}^{+}+\beta_{2}^{+-} e c m_{t-1}^{+} \Delta c r_{t}^{-}+\beta_{3}^{-+} e c m_{t-1}^{-} \Delta c r_{t}^{+}+\beta_{4}^{--} e c m_{t-1}^{-}+ \\
+\sum_{i=0}^{2} \gamma_{i} \Delta s_{t-i}+\sum_{i=0}^{2} \phi_{i} \Delta r s_{t-i}+\varepsilon_{t}
\end{gathered}
$$

Single stage asymmetric double threshold error correction model (DT-ECM)

$$
\begin{aligned}
& \Delta r s_{t}= \\
& \begin{aligned}
\alpha_{0}+\beta_{1}^{++} e c m_{t-1}^{+} \Delta & c r_{t}^{+}+\beta_{2}^{+-} e c m_{t-1}^{+} \Delta c r_{t}^{-}+\beta_{3}^{-+} e c m_{t-1}^{-} \Delta c r_{t}^{+}+\beta_{4}^{--} e c m_{t-1}^{-} \Delta c r_{t}^{-}+ \\
& +\sum_{i=0}^{2} \gamma_{i} \Delta c r_{t-i}+\sum_{i=0}^{2} \delta_{i} \Delta e r_{t-i}+\sum_{i=0}^{2} \phi{ }_{i} \Delta r s_{t-i}+\varepsilon_{t}
\end{aligned}
\end{aligned}
$$

As shown in Tables 6 to 8 , the nonlinear error correction terms with double thresholds of equations (13)-(15) are significant. The main difference of this nonlinear model with prior models discussed in the literature is that it focuses on double short-run asymmetries based on ecm terms ${ }^{15}$. Apart from these two interactions between the

\footnotetext{
${ }^{15}$ Cotín et al. (2008), focused on single short-run asymmetries and they found almost none.
} 
asymmetric error correction terms and the dummies for crude price increases and decreases, the model includes some by short run dynamics to make sure that the residuals are white noise. The short-run dynamics follows an autoregressive distributed lag (ARDL) form in first differences, with the contemporaneous effects of the independent variables and their lags together and lags of the dependent variable (see Table 6-Table 8). The choice of the number of lags has been selected by minimizing the information criteria (Akaike Information Criterion, Bayesian Information Criterion and Hannan-Quinn Information Criterion). Furthermore we also tested if the residuals were homoscedastic (White test) and uncorrelated (Breusch-Godfrey LM tests). There is no evidence of second order autocorrelation, $\operatorname{AR}(2)$, but there was evidence of heteroskedasticity and therefore we used White's robust standard errors.

Table 6-Table 8 and Figure 6 present the estimated coefficients of the error correction terms used in equations (15)-(17) for Spain. This estimation gives a first idea of the long-run asymmetry by looking at the significance and the magnitude of the coefficients as in Granger and Lee (1989). Most of the long-run coefficients represented in Table 6Table 8 are significant except two of them.

Besides significance, comparing the absolute values of the coefficients suggests various remarks. Traditional literature has focused on the comparison between the coefficients of the $\mathrm{ecm}^{+}$and the $\mathrm{ecm}^{-}$, which represent the velocity of adjustment towards equilibrium. Economic intuition states that when the error correction term $(e c m>0)$ is positive, it is because the current price is above its expected long-run equilibrium, therefore prices are higher than expected and they will tend to decrease in the next period to adjust to the equilibrium. Nevertheless, when the error correction term is negative $(e c m<0)$, it is because the current price is below the long-run equilibrium and it will increase in the next period to reach the equilibrium.

Figure 6: Asymmetric error correction terms for 2011-2016
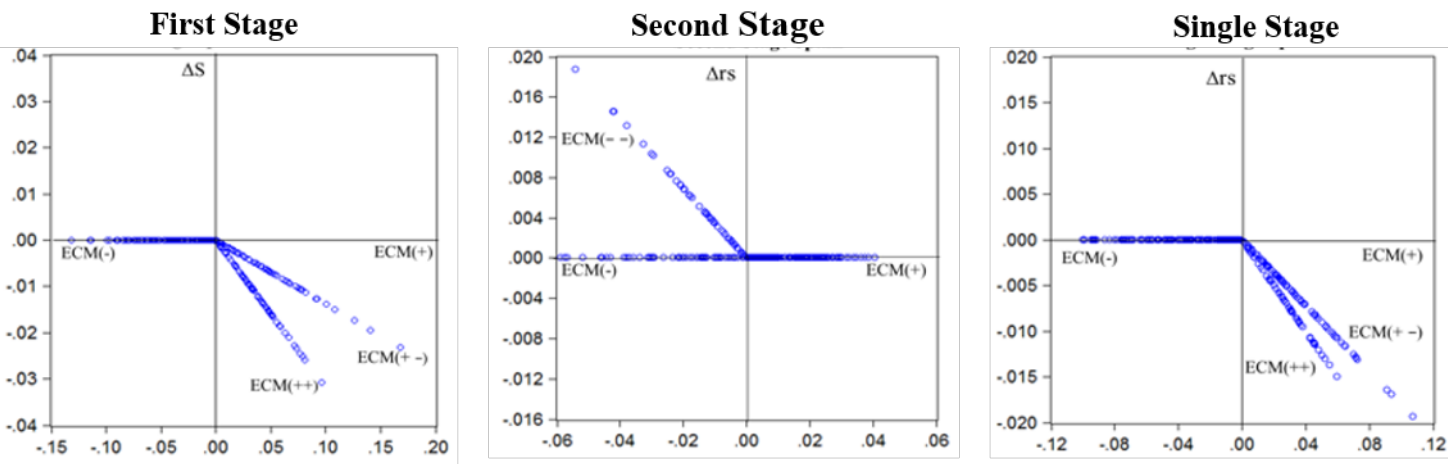

Note. The figure shows the long-run asymmetries found in all the segments of the market for Spain during 2011-2016. The meaning of the two signs within the brackets of the ECM(++) represents the first one, whether the price is above (positive sign) or below (negative sign) its long run equilibrium and the second one, whether crude oil prices are increasing (positive sign) or decreasing (negative sign).

Apart from ensuring that the coefficients for the error terms are individually significant, it is important to perform an F-test to test if those numerical divergences are significant. On the one hand, under the null hypothesis, $H_{0}: \beta^{++}=\beta^{+-}$and $H_{0}: \beta^{-+}=\beta^{--}$, the test checks the long-run asymmetry in prices depending on whether crude oil prices are increasing or decreasing. Rejecting these hypotheses imply that prices adjust 
differently depending on the sign of crude price changes. On the other hand, if the null, $H_{0}: \beta^{++}=\beta^{-+}$and $H_{0}: \beta^{+-}=\beta^{--}$is rejected; this provides evidence that persistent asymmetries exists between positive and negative error correction terms, when crude prices are rising or falling. Table 9 shows the results obtained from these tests, where asymmetries are found in all the segments of the market.

By combining the results of the test in Table 9 and the coefficients in Table 6-Table 8, some conclusions can be drawn. For the first and the single stage models, the coefficients associated with positive error correction terms are greater than the ones for negative error correction terms. Therefore, it seems that prices are above their equilibrium. This could be explained by some of the theories that we will mention in section 6, such as the existence of market power, consumer search costs or asymmetric adjustment costs. Furthermore, the speed of adjustment is larger when crude prices are increasing than when they are decreasing. Results differ for the second stage, where different conclusions are reached. In this segment of the market, the coefficients associated with negative error correction terms are greater than those of positive error correction terms. Hence, retail prices are below equilibrium. This could have been a consequence of the recession. If companies know that people are facing financial difficulties, they will slowly adjust prices to avoid a sharp fall in fuel demand.

Table 9: F-tests for asymmetric adjustment, $p$-values

\begin{tabular}{|c|c|c|c|c|c|}
\hline \multicolumn{6}{|c|}{ Spain } \\
\hline First Stage & & Second Stage & & Single Stage & \\
\hline$H_{0}: \beta_{1}^{++}=\beta_{2}^{+-}$ & 0.066 & $H_{0}: \beta_{1}^{++}=\beta_{2}^{+-}$ & - & $H_{0}: \beta_{1}^{++}=\beta_{2}^{+-}$ & 0.385 \\
\hline$H_{0}: \beta_{3}^{-+}=\beta_{4}^{--}$ & - & $H_{0}: \beta_{3}^{-+}=\beta_{4}^{--}$ & 0.000 & $H_{0}: \beta_{3}^{-+}=\beta_{4}^{--}$ & - \\
\hline $\boldsymbol{H}_{0}: \boldsymbol{\beta}_{1}^{++}=\boldsymbol{\beta}_{3}^{-+}$ & 0.000 & $H_{0}: \beta_{1}^{++}=\beta_{3}^{-+}$ & - & $H_{0}: \beta_{1}^{++}=\beta_{3}^{-+}$ & 0.000 \\
\hline$H_{0}: \beta_{2}^{+-}=\beta_{4}^{--}$ & 0.066 & $H_{0}: \beta_{2}^{+-}=\beta_{4}^{--}$ & 0.000 & $H_{0}: \beta_{2}^{+-}=\beta_{4}^{--}$ & 0.003 \\
\hline
\end{tabular}

Note. Entries are the p-values computed from the F-test for the null hypothesis of symmetry. Under the null, coefficients should be equal, representing the same speed of adjustment towards the long-run equilibrium.

\section{Economic explanations of the asymmetries}

With numerous studies showing that asymmetries exists in the fuel market for several countries, economists offer different theories to explain this phenomenon.

Market power-collusion. Economic theory suggests that asymmetric movements in prices are connected with imperfect competition. According to Borenstein et al. (1997), tacit collusion can be considered to be the main driver of price asymmetries. On the one hand, when international crude oil prices decrease, retailers would be initially reluctant to lower their prices to avoid the risk of starting a price war. On the other hand, when oil prices increase, retailers would raise gasoline prices quickly in order to maintain their profit margins. This rapidly increase in retail prices would convince their competitors that they are loyal to the collusive agreement and deviations from that equilibrium will not occur. Following Motta (2004), the Spanish fuel market satisfy almost all the characteristics that facilitate collusion. Firstly, there are several entry barriers in all its segments. Examples of legal barriers are the CODO or DODO agreements, which could give rise to foreclosure effects. Furthermore, the fuel market 
is characterised for being vertically integrated and with a higher $\mathrm{HHI}$. As a consequence, independent retailers, which are not vertically integrated would probably suffer from higher supply costs due to less beneficial clauses from supply contracts. Furthermore, distribution through CLH can be considered as another entry barrier. Secondly, the fuel demand is very inelastic and the lack of coordination power among consumers allows for anti-competitive practices. Thirdly, the market is very transparent since daily prices are publicly available at the website of the Ministry of Industry, Tourism and Trade. Therefore, each retailer has access to its competitors' prices.

Consumer theory-search costs. Search costs are defined as the time, energy and money spent by consumers when searching for a product. Its existence implies that individual buyers do not always have enough information to take their decisions. Particularly, it is considered that consumers perceive higher search costs when prices decrease than when they increase. Therefore, buyers seek for best prices more actively when prices raise. It generates lower pressure on retailers when prices fall, allowing them to reduce competition and maintain tacit collusion (Brown and Yucel, 2000). Thanks to the public access to daily prices, this type of costs can be reduced in principle. According to the Ministry of Industry, Tourism and Trade, the 19th of May 2016, the price of 95 octane gasoline in Madrid vary in $0.187 € /$ /itre from the cheapest to the most expensive petrol station. If your car consumes approximately one deposit of 60 litres per month, you weekly save $2,805 €$ if you go to the cheapest service station. However, the time spent looking for this offer and the transport costs of reaching the petrol station are probably greater than the money saved.

Firm's theory-adjustment costs. A less critical argument for oil companies is based on inventory management adjustments, accounting practices, lags in production or asymmetric storage costs. When international crude oil prices fall, national demand increases slightly. Given that the refinery process takes some weeks, market operators raise their sales by reducing the fuel storage, which increments average storage costs. However, when international crude oil price rises, national demand decreases slightly. This provokes a temporary increase in stock, which reduces the average storage costs since operators can take advantage of the economies of scale.

\section{Conclusions}

This paper tested the consumers' complaint that retail gasoline prices react faster to crude oil price increases than to decreases. The relevance of fuel products into people's daily lives have attracted the attention of economists and competition authorities, which have studied the fuel market in detail for several countries. So far, no consensus has been reached for the Spanish sector since most of empirical analysis previously done did not find strong empirical evidence of asymmetric price behaviour.

In comparison with traditional asymmetric price theory literature, this study introduces new double threshold nonlinear models and compares them with the more common linear error correction models; threshold autoregressive ECM models (T-ECM), smooth transition regression (STR) models and nonlinear error correction (NEC) models.

This empirical research was performed using updated weekly data for the 2011-2016 period. To tackle the rockets and feathers phenomenon new double asymmetric and Logistic ECM were carried out. These new models employed gain flexibility by introducing double threshold error correction terms; the error correction terms not only 
depends on whether the error is positive or negative but also on whether the crude oil prices are rising or falling. Furthermore, the different nonlinear ECM's are developed for the different stages of the production and distribution chain. This approach allows us to identify in which segment of the market long-run asymmetries occur.

The results obtained show that long-run asymmetries exist and they differ with the stage and with the period analysed. However, with the first and the single stage models net outcomes are similar for all time periods.

The coefficients associated with positive error correction terms are greater (in absolute value) than the ones for negative error correction terms. Therefore, the cointegrated prices tend to be above their long run equilibrium values. This behaviour of the oil companies could be justified by the existence of market power, consumer search costs and/or asymmetric adjustment costs. The speed of adjustment was higher when crude prices were increasing than decreasing.

However, in the second stage of the Spanish market, parameters associated with negative error correction terms were greater than those of positive error correction terms. Hence, retail prices were mainly below equilibrium, which might be a consequence of the recession since the 2007/08 financial crisis or a reaction to compensate for the otherwise very clear asymmetric price behaviour.

\section{References}

Adams, W., Brock, J., 1983. Deregulation or divestiture: The case of petroleum pipelines, Wake Forest Law Review, vol. 19 (5): 705-791.

Bachmeier, L.J., Griffin, J.M., 2003, New evidence of asymmetric gasoline price responses, Review of Economics and Statistics, 85(3), 772-776.

Bacon, R. W., 1991. Rockets and feathers: the asymmetric speed of adjustment of UK retail gasoline prices to cost changes. Energy economics, 13 (3), 211-218.

Balke, N. S., Brown, S. P. A., Yücel, M. K., 1998, Crude oil and gasoline prices: An asymmetric relationship", Economic Review, first quarter, 2-11.

Balmaceda, F., Soruco, P., 2008. Asymmetric dynamic pricing in a local gasoline retail market. The Journal of Industrial Economics, 56(3), 629-653.

Bettendorf, L., Van der Geest, S. A., Varkevisser, M., 2003. Price asymmetry in the Dutch retail gasoline market. Energy Economics, 25(6), 669-689.

Bettendorf, L., van der Geest, S. A., Kuper, G. H., 2009. Do daily retail gasoline prices adjust asymmetrically? Journal of Applied Statistics, 36(4), 385-397.

Borenstein, S., Cameron, C. A., Gilbert, R. 1997. Do gasoline prices respond asymmetrically to crude oil price changes?, Quarterly Journal of Economics, 112, 305339.

Brown, S. P., Yucel, M. K., 2000. Gasoline and crude oil prices: why the asymmetry? Economic and Financial Review, 23.

Comisión Nacional de Energía, 2012. El mercado español de la distribución de gasolina y gasóleo a través del canal de estaciones de servicio. Madrid. 
Comisión Nacional de la Competencia, 2012. Informe de seguimiento del mercado de distribución de carburantes de automoción en España. Madrid.

Comisión Nacional de los Mercados y la Competencia, 2015. Study of the wholesale automotive fuel market in Spain. Madrid.

Correljé, A., 1994. The Spanish oil industry: Structural change and modernization. Amsterdam: Tinbergen Institute Research Series, vol.84. Thesis Publishers.

Cotín-Pilart, I., Correljé, A. F., Navarro, M. B. P. 2008. (A) Simetrías de precios y evolución de márgenes comerciales en el mercado español del gasóleo de automoción. Hacienda Pública Española, (185), 9-37.

Deltas, G., 2008. Retail gasoline price dynamics and local market power. The Journal of Industrial Economics, 56(3), 613-628.

Dickey D.A, and W.A. Fuller (1979). Distribution of the Estimators fro Autoregressive Time Series with a Unit Root". Journal of the American Statistical Association, 74, 427431.

Dufrénot G. and V. Mignon (2002). Recent Developments on Nonlinear Cointegration with Applications to Macroeconomics and Finance. Kluwer Academic Publishers.

Enders W. and C.W.J. Granger (1998). "Unit-root test and asymmetric adjustment with an example using the term structure of interest rates". Journal of Business and Economic Statistics, 16, 304-311.

Engle, R. and C. Granger. 1987. Cointegration and error correction: Representation, estimation and testing. Econometrica 55: 251\{276.

Escribano A. 1986. Identification and modelling of economic relationships in a growing economy. PhD Thesis, University of California San Diego.

Escribano A. 2004. Nonlinear error correction: The case of the money demand in UK (1878-2000). Macroeconomics Dynamics, 8, 76-116.

Escribano, A. and C.W.J. Granger, 1998. Investigating the Relationship Between Gold and Silver Prices. Journal of Forecasting. Vol. 17, 81-107, 1998.

Escribano A. and G.Pfann, 1998. Nonlinear error correction, asymmetric adjustment and cointegration. Economic Modelling 15, 197-216.

Escribano A. and O. Jordá, 1999. Improved testing and specification of smooth transitions regression models, in P. Rothmand (ed.), Nonlinear Time Series Analysis of Economic and Financial Data. Kluwer Academic Publishers, 289-319.

Escribano A. and O. Jordá, 2001. Testing Nonlinearity: Decision Rules for Selecting between Logistic and Exponential STAR Models. Spanish Economic Review. 3, 193209.

European Commission, 2006. COMP/B1-38.348 - Repsol (2006/C 152/06) Final report of the Hearing Officer in case (pursuant to Articles 15 and 16 of Commission Decision (2001/462/EC, ECSC) of 23 May 2001 on the terms of reference of Hearing Officers in certain competition proceedings - OJ L 162, 19.6.2001, p. 21)

Franses P. H. and D. Van Dijk, 2000. Non-linear time series models in empirical finance. Cambridge University Press. 
Granger C.W.J and T.H. Lee, 1989. Investigation of production, sales and inventory relationships using multicointegration and non-symmetric error correction models. Journal of Applied Econometrics 4, 145-159.

Galeotti, M., Lanza, A., Manera, M., 2003. Rockets and feathers revisited: an international comparison on European gasoline markets. Energy economics, 25(2), 175-190..

Jiménez, J. L., Perdiguero, J., 2005. Medición de la colusión a través del parámetro de conducta: el caso de los hidrocarburos en Canarias. Mimeo.

Johnson, R. N., 2002. Search costs, lags and prices at the pump. Review of Industrial Organization, 20(1), 33-50.

Mackinnon J. 1996. Numerical distribution functions for unit root and cointegration tests. Journal of Applied Econometrics, 11, 601-618.

Mercuri, P., 2001. Asimetrías en la Respuesta de los Precios de los Combustibles Líquidos a cambios en el Precio del Crudo: el Caso Argentino. Asociación Argentina de Economía Política.

Motta, M., 2004. Competition Policy: Theory and Practice. Cambridge University Press.

Peltzman, S., 2000. Prices rise faster than they fall. Journal of Political Economy, 108(3), 477-502.

Perdiguero, J., 2010. Dynamic pricing in the Spanish gasoline market: a tacit collusion equilibrium. Energy Policy, Vol. 38(4), pp. 1931-1937.

Phillips, P.D.B. and B.E. Hansen, 1990. Statistical Inference in Instrumental Variables Regression with I(1) Processes. Review of Economic Studies 57, 99-125.

Stock, J.H. and M. Watson, 1993. A simple estimator of cointegrating vectors in higher Order integrated systems, Econometrica, 61, 783-820.

Teräsvirta T. 1994. Specification, estimation and evaluation of smooth transition autoregressive models. Journal of the American Statistical Association, 89, 208-18.

Teräsvirta T. 1996. Power properties of linearity test for time series. Studies in Nonlinear Dynamics and Econometrics, 1, 3-10.

Teräsvirta T. and A. C. Eliasson 2001. Nonlinear error correction and the UK demand for broad money, 1878-1993". Journal of Applied Econometrics, 16, 277-88.

Teräsvirta, T., D. Tjostheim and C.W.J. Granger, 2010. Modelling Nonlinear Economic Time Series. Oxford University Press. 